\begin{tabular}{|c|c|c|c|}
\hline & $\begin{array}{r}\text { Anna } \\
\text { http://wv }\end{array}$ & $\begin{array}{l}\text { Journal } \\
\text { sindex.php }\end{array}$ & \multirow{2}{*}{ 2. } \\
\hline & Print ISSN : 2278-9839 & Online ISSN : 2393-9885 & \\
\hline
\end{tabular}

Review article

\title{
DNA fingerprinting in industrially important medicinal trees
}

\author{
Rekha R Warrier , Geeta Joshi* and A.N. Arunkumar* \\ Institute of Forest Genetics and Tree Breeding (IFGTB), P.B.No.1061, R.S.Puram, Coimbatore-641002, T.N. India \\ *Tropical Forest Research Institute (TFRI), PO R.F.R.C., Mandla Road, Jabalpur-482021, India
}

Received April 25, 2019: Revised June 15, 2019: Accepted June 20, 2019: Published online June 30, 2019

\begin{abstract}
Herbal medicine has been considered as a promising future medicine for the management of healthcare. The shift "Return back to Nature" has enhanced the consumption of plant-based phytomedicines and other botanicals in recent years. Medicinal plants are considered as rich sources of phytochemical ingredients. With a big gap in the demand and supply, there is heavy exploitation of these resources. The fast depleting are the medicinal trees, which, due to their long gestation, fails to find a place in cultivation. There is a need to encourage cultivation of these species. Traditional breeding and biotechnology can be used in their genetic improvement. Environmental conditions affect the active constituents of medicinal plants and, therefore their activity profiles. Hence, there is a need to understand the geographical variation at the genetic level. DNA-based techniques have been widely used for assessing diversity and authentication of plant species of medicinal importance. This paper describes the demand of some medicinal trees which are in high demand in the Ayurvedic industry, and the application of DNA techniques to understand the geographic distribution, authentication and confirmation of identity of the species.
\end{abstract}

Keywords : Molecular markers, authentication, genetic variation, medicinal trees

\section{Introduction}

India prides in practicing some of the very old systems of medicine that continue to be the mainstay of healthcare delivery to a very large segment of its population even today (Manoharachary and Nagaraju, 2016). These Indian Systems of Medicine are finding increasing acceptance globally also. Their continuance is largely dependent upon assured supply of quality herbal raw material. Indian herbal medicine industry recognizes the importance of conservation of these valuable bioresources and encourages their cultivation (Narayana and Johnson, 2017). Nearly, 1200 medicinal plant species are in commercial use by the domestic herbal industry and traditional practitioners (Goraya and Ved, 2017).

The National Medicinal Plants Board in India has been making efforts to strengthen the medicinal plants resource base in the country through conservation and cultivation. Some of the species have been successfully domesticated and brought under cultivation. The Indian Council of Forestry Research and Education (ICFRE) has been making significant contribution to the strengthening of medicinal plants resource base through development of domestication and cultivation protocols in respect of various medicinal plant species of conservation concern.

\subsection{Indian medicinal industry}

Healthcare market and medical devices market in India is expected to reach US $\$ 372$ billion and US $\$ 11$ billion by 2022 . The usage of herbal products in Indian households has increased from $69 \%$ in

\footnotetext{
Author for correspondence: Dr. Rekha R. Warrier

Scientist-E, Institute of Forest Genetics and Tree Breeding (IFGTB), P.B.No. 1061, R.S. Puram, Coimbatore-641002, Tamil Nadu, India E-mail: rekhawarrier@gmail.com

Tel.: +91-9442918647; +91-4222484167
}

Copyright (ㅇ 2019 Ukaaz Publications. All rights reserved.

Email: ukaaz@yahoo.com; Website: www.ukaazpublications.com
2015 to $77 \%$ in 2017 (The Economic Times, 2018). It is predicted that global Ayurvedic market would increase by three folds in 2022 (TOI, 2018) with a contribution of US\$ 9.7 billion compared to that of US\$ 3.4 billion in 2015 .

Among various Indian System of Medicine practitioners, the largest share is Ayurveda system contributing 55.4\% share (IBEF, 2019). During 2014-15, it was estimated that the domestic and international demand for medicinal plants was 1,95,000 MT and 1,34,500 MT, respectively. Considering the herbal drug market, it is estimated that the total consumption in India for the year 2014-15 was 5,12,000 MT which amounted to trade value of 5,500 crore rupees. There has been approximately nine fold increase in export value from Rs. 345.80 crore to Rs. 3211 crore in $2005-06$ to 2014-15 (NMPB, 2019). With this sort of continuous increase in demand for crude drugs and natural products, a big challenge that emerges in this scenario is protecting the highly valued medicinal plant resources from over exploitation and habitat destruction (Srivastava et al., 1996).

\subsubsection{Demand for species}

Medicinal plants are not only a major resource base for the traditional medicine and herbal industry but also provide livelihood and health security to a large segment of Indian population. The domestic trade of the AYUSH industry is of the order of Rs. 80 to 90 billion (Biradar, 2015). In India, out of 17 to 18 thousand species of flowering plants, considering the folk and documented systems of medicine, more than 7000 species have one or the other medicinal properties. Out of these, 1178 species are traded in the market and 242 species are known to have consumption demand of more than 100 metric tons per year. The number of botanicals traded is estimated to vary from 400 as per the report on medicinal plants commissioned by Planning Commission of India (Anon, 2002) to 1500 as per Jain (1996). However, Bode (2004) mentioned that for 
production of Unani medicines, Hamdard Pharmaceutical Company uses more than 2000 fruits, shrubs, leaves, metals, minerals as well as animals. Due to enormous demand for Ayurveda products, industries have resorted to huge production of herbal products (Nayanabhirama, 2016). Large quantities of plant raw material is needed which is mostly harvested from the wild (Valiathan, 2006; Goraya and Ved, 2017; Joshi et al., 2017).
Though, cultivation of medicinal plants is gaining momentum in the recent years, yet consumption from the wild sources continues to be the first choice. The NMPB report (Ved and Goraya, 2008) reveals that of the 1178 species used, nearly $53 \%$ of these species are subjected to destructive harvest while in 2018, the authors report that 582 species $(66 \%)$ are reported to be harvested destructively (Figure 1).

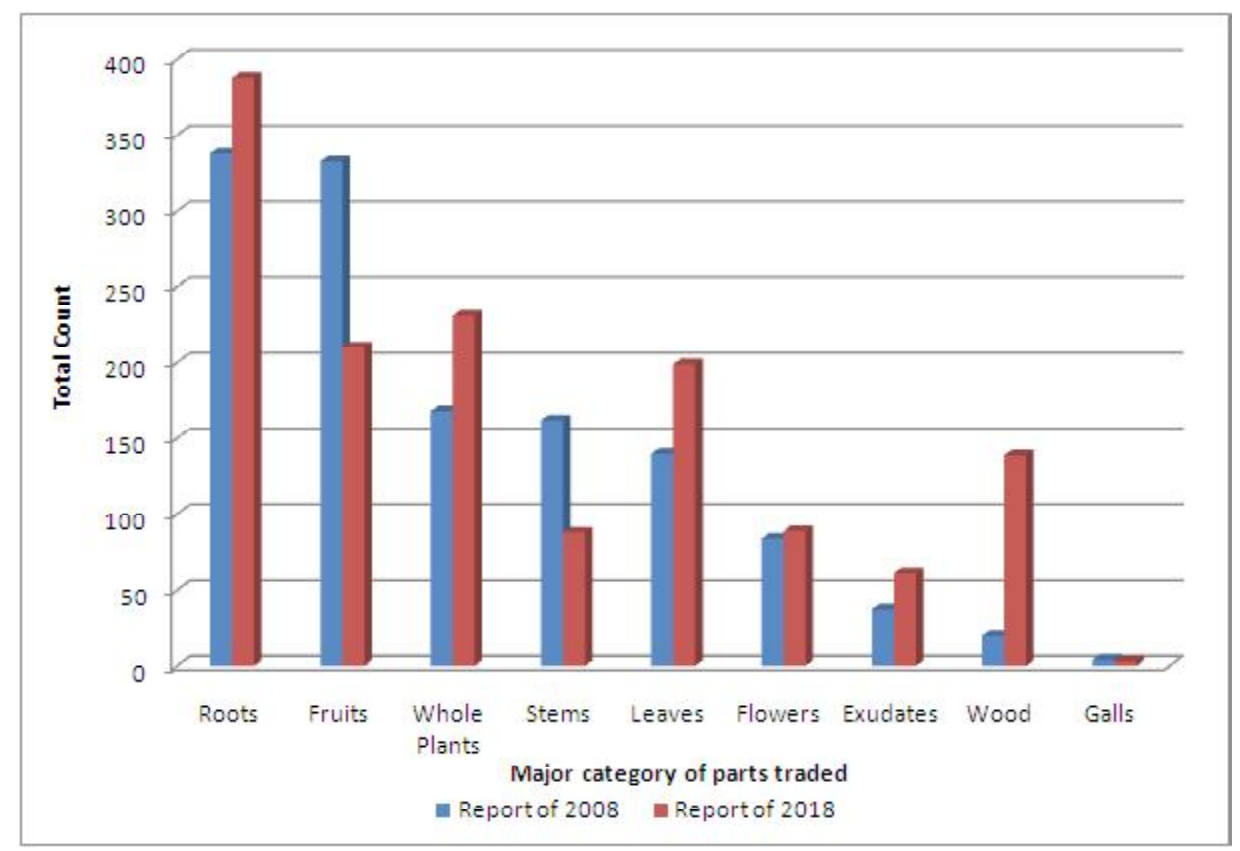

Figure 1: Part-wise distribution of herbal raw drugs in commercial demand in 2008 and 2018

India exports a large number of botanical raw drugs to many countries across the globe. United States of America has been the largest importer of botanical raw drugs from India. An average annual increase of $11 \%$ in export volumes of botanical raw drugs, recorded from 2005 to 2015, reveals significant increase (Figure 2).

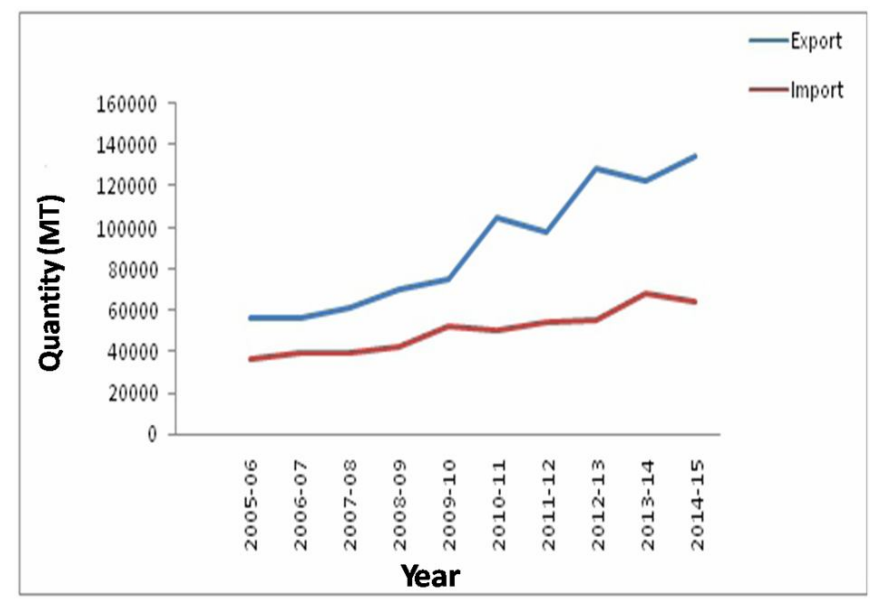

Figure 2: Gross volume of foreign trade of botanical raw drugs (Goraya and Ved, 2017).

\subsubsection{Markers}

Authenticity of the raw drugs used in various preparations is presently the major concern of the growing herbal sector. Though, the use of acceptable substitutes, in case of non-availability of the original entity has been suggested in classical texts, inexperience of wild gatherers results in collection of look alike species, leading to adulteration. The other is deliberate mixing of foreign or inferior material in the accepted herbal raw drug with an intent to enhance the returns.

For safety and efficacy of herbal medicine, one of the most essential aspect is the correct identification of the species, proper extraction of constituents and its subsequent quality assurance so that, 
reproducible quality of herbal medicine is achieved (Joshi et al., 2004). To attain this, most of pharmacopoeias and regulatory guidelines suggest that the botanical material has to undergo suitable pharmacognostic techniques in the form of micro and macroscopic evaluation along with proper chemical profiling for quality control and standardization (WHO, 1996).

Some of the innovative technologies such as high throughput screening (HTS) and recent advances in extraction, chromatographic techniques like TLC and HPLC, electrophoresis and spectroscopy generally use those chemical markers that may not be active therapeutically. Apart from that, secondary metabolites which are considered as markers may not be stable as they are liable to changes due to environmental factors may also create hindrance in correct identification of active principles or chemical constituents.

To overcome these difficulties, use of ubiquitous molecular markers is gaining prominence. Molecular markers identify plants at genomic level and establish new standards in for quality control of botanicals (Joshi et al., 2004). With the advancement in the field of genetics and molecular biotechnology, for authentication of herbal materials at DNA level, genetic tools are considered to be more reliable (Kumar et al., 2009). For species characterization in medicinal plants, various DNA-based markers are being extensively used now (Shaw et al., 2002; Zhang et al., 2007; Sucher and Carles, 2008). This technology is also useful specially in cases of those species which are frequently adulterated, substituted or in cases where it is difficult to distinguish samples having morphological or chemical similarity.

One of the main issues of chemical fingerprinting is that the signature is strongly influenced by some of the intrinsic as well as external factors such as age of the sample, physiological, environmental factors, cultivation area, harvesting period and process, drying and storage conditions, etc. However, DNA is extremely stable and not influenced by external factors, easily recovered from either fresh or dried material and sometimes even from processed biological material. Moreover, the molecules are not tissue specific and are required in very small quantity.

\subsubsection{Authentication of herbal material on the DNA level}

DNA based approaches are useful analytical tools for assessing and assuring the quality of herbs / herbal products (Parveen et al., 2016). Using short and standardized gene regions, known as 'barcodes', DNA barcoding technique is cost effective and suitable for species level identification (Hebert et al., 2003). In India, the herbal drug markets were surveyed, and the authenticity of the herbal drugs has been tested using DNA barcoding.

It was found that raw drugs in Indian herbal markets were not genuine to the tune of $21 \%$ (Vassou et al., 2016). Out of 93 herbal products sold in the form of plant powders, capsules and in local stores in India, 60 per cent were adulterated (Shanmuganandhan et al., 2016). Raw drug samples obtained from Phyllanthus amarus showed 24 per cent substitution with phenotypically similar species of Phyllanthus (Srirama et al., 2010).

Substitution has also been reported in Cinnamomum verum by $70 \%$ (Swetha et al., 2014); Myristica fragrans by $60 \%$ (Swetha $e t$ al., 2017); Senna auriculata by 50\%, Senna tora by $37 \%$ and Senna alexandrina (8\%) (Seethapathy et al., 2015) and Sida cordifolia by 76\% (Vassou et al., 2015, 2016).
Studies to authenticate herbal products obtained from various species by combining spectroscopic methods such as NMR along with DNA bar coding or microscopy reported $80 \%$ in Berberis aristata (Srivastava and Rawat, 2013), 22\% in Piper nigrum (Parvathy et al., 2014) and $80 \%$ adulteration in Saraca asoca (Urumarudappa et al., 2016). Various such studies on herbal products have shown concern about the quality and good labeling practices (Veldman et al., 2017; Seethapathy et al., 2019).

\subsubsection{Diversity analysis}

Medicinal plants are the primary raw material for pharmaceutical drugs. They differ in quality depending on the populations. Knowledge about inherent variability is required for conservation, and/or protection of genetic diversity. For optimum genetic improvement and resource management, developing conservation strategies and sustainable utilisation of medicinal plants resources, documenting and understanding the genetic variation within and among the population is a basic step.

It is an accepted fact that due to increased demand for medicinal plants, natural populations are extensively exploited. For its long term survival as well as extensive semi-domestication success, the essential factor needs immediate attention is to maintain sufficient genetic variability. This would also provide options for developing superior genotypes by human interference as well as accommodating natural selection pressures as a result of continuous environmental changes (Barrett and Kohn, 1991).

In India, medicinal plants are gaining popularity and cultivated extensively by farmers, however, it is to be noted that many of the species are still semi-domesticated in nature. Numerous studies have been carried out to understand the impact of cultivation on genetic diversity of crop plant as well as tree species (Bahulikar $e t$ al., 2004; Shaanker et al., 2004; Bodare et al., 2013; Harish et al., 2014). However, studies are still to be carried out to understand the changes in genetic structure of various species due to impact of environmental factors like variation in latitude, longitude along with meteorological variables (Britto et al., 2009; Haji et al., 2014; Panda et al., 2015).

Not many medicinal plants have been evaluated for genetic diversity and gene pool wealth. There is no data to support how much of any species can be harvested on a sustainable yield basis-without reducing existing populations. Basic research on reproductive biology, population dynamics and demographics of medicinal species is yet to be conducted (Rao, 2016).

In the last three decades, three classes (Gupta et al., 2001) of markers have been developed. The first generation molecular markers include restriction fragment length polymorphism (RFLP), randomly amplified polymorphic DNA (RAPDs) and their modifications. This was followed by inter simple sequence repeats (ISSR), simple sequence repeats SSRs, amplified fragment length polymorphism (AFLP) and their modified forms which formed the second generation. The current day markers in vogue are ESTs and SNPs the third generation markers.

\section{First generation markers}

RAPD-based molecular markers helped to differentiate different accessions of Andrographis paniculata (Fu et al., 2003), Atractylodes (Kohjyouma et al., 1997), Glycirrhiza (Yamasaki et al., 1994) and 
Piper nigrum (Khan et al., 2010). The markers differentiated related species as in the case of Lycium barabarum (Zhang et al., 2001), Scutellaria (Hosokawa et al., 2000), Melissa officinalis (Wolf et al., 1999). The markers were also efficient in identifying adulterants of species like Ammomum villosum (Wang et al., 2000), Panax sp. (Shim et al., 2003), Cuscuta (Khan et al., 2010) and Echinacea (Nieri et al., 2003). Modifications of the RAPD has been applied to authenticate Herba species (Cao et al., 1996; 1997) and Magnolia officinalis (Wang et al., 2001). Similarly, RFLP was also used to identify Fritillaria (Tsoi et al., 2003; Wang et al., 2005), Rheum (Yang et al., 2004) and Dendrobium (Li et al., 2005).

\section{Second generation markers}

The advent of AFLP not only helped in distinguishing closely related individuals at the sub-species level but also in mapping genes. Species-specific markers were developed to identify different Swertia species (Misra et al., 2010). An AFLP map was generated for Cannabis (Datwyler et al., 2006). ISSR analysis represented a compromise between AFLP and RAPD. It was used to identify Cistanche (Shi et al., 2009), Fritillaria (Li et al., 2009), Salvia (Song et al., 2010), Vitex (Hu et al., 2007), Cannabis (Kojoma et al., 2002) and the confirmation of Dendrobium officinale (Shen et al., 2006). SSRs were used to identify Panax ginseng (Kim et al., 2007), Acanthopanax senticosus (Kim et al., 2007), Dendrobium fimbriatum (Fan et al., 2009), Cymbopogon species (Kumar et al., 2007), Bupleurum (Chun et al., 2009) and Schisandra (Boqian et al., 2009).

\section{Third generation markers}

Sequence characterized amplified region (SCAR) is a PCR based marker, generated from polymorphic regions, differing in size between species, It also permits sample authentication on the basis of SCAR size shifts. SCAR markers are highly efficient and robust. SCAR markers have high detection efficiency as the SCAR primers are able to retrieve a single clear band from the genuine sample, differentiating it from the adulterants. A 320 bp SCAR marker was developed for distinguishing P. tuberosa from Adenia hondala, Cycas circinalis and Ipomea mauritiana (Devaiah et al., 2010). SCAR primers were designed to get unique bands for Embelia ribes, to identify it from the adulterants (Devaiah et al., 2008).
Phyllanthus amarus was distinguished using SCAR primers from P. debilis and $P$. urinaria, which are morphologically similar (Theerakulpisut et al., 2008). Development of SCAR markers have been done for Zingiber also (Chavan et al., 2008). Seethapathy et al. (2014) authenticated Aconitum heterophyllum and Cyperus rotundus using nrDNA ITS sequence based SCAR markers.

Cultivar-specific SNP markers and established real-time allelespecific PCR system have been applied for molecular authentication, seed purity testing, and the marker assisted selection of the narrow genetic base of $P$. ginseng cultivars (Wang et al., 2016). To evaluate genetic structure of cultivated varieties and populations in Chamomile, Genotyping-by-sequencing (GBS) was used. The study focussed on genes having larger effect on flowering time and alphabisabolol content (Otto et al., 2017). SNP markers in rbcL and matK genes from the chloroplast genome helped to recognize C. denticulatum from other related taxa (Do et al., 2019).

\subsubsection{DNA barcoding}

DNA barcoding can be an accurate and reliable alternative to morphological identification for biological material (Hebert et al., 2003). It is now regularly used when identification using macroscopic or microscopic methods is difficult. Parvathy et al. (2014) used DNA barcodes to detect adulteration in traded black pepper powder while Rai et al. (2012) developed DNA barcodes from ITS2 region for Asparagaceae and Asclepiadaceae members.

DNA barcodes have been used for authentication of Ginkgo biloba dietary supplements (Little, 2014) and molecular authentication of Peucedanum praeruptorum (Zhou et al., 2014). Enan and Ahamed (2014) identified DNA barcodes from plastid matK and RNA polymerase for assessing the genetic identity of date cultivars while Chandramohan et al. (2013) used the same for molecular characterization of Croton bonplandianum. Vassou et al. (2015) reported the efficiency of DNA barcoding for species identification from powdered plant parts of Sida cordifolia from the raw drug market. Plant barcodes rbcL, matK, trnH-psbA, and ITS2 have been tested in a wide variety of plant species

Table 1: Limitations of genetic markers

\begin{tabular}{|c|c|c|c|c|c|c|}
\hline RAPD & RFLPs & SSR & AFLP & ISSR & SCAR & Barcodes \\
\hline $\begin{array}{l}\text { Less } \\
\text { reproducible } \\
\text { marker }\end{array}$ & $\begin{array}{l}\text { Limited sensitivity } \\
\text { of detection }\end{array}$ & $\begin{array}{l}\text { Time } \\
\text { consuming }\end{array}$ & $\begin{array}{l}\text { Involves radioactive } \\
\text { materials (overcome } \\
\text { using fluorescent } \\
\text { tags) }\end{array}$ & $\begin{array}{l}\text { Less } \\
\text { reproducible } \\
\text { marker }\end{array}$ & $\begin{array}{l}\text { Prior knowledge } \\
\text { on sequence } \\
\text { data essential }\end{array}$ & $\begin{array}{l}\text { Fails to } \\
\text { distinguish } \\
\text { recently } \\
\text { diverged } \\
\text { species }\end{array}$ \\
\hline \multirow[t]{3}{*}{$\begin{array}{l}\text { Dominant } \\
\text { marker }\end{array}$} & $\begin{array}{l}\text { Laborious and } \\
\text { difficult to } \\
\text { automate }\end{array}$ & Costly & $\begin{array}{l}\text { Purified and high } \\
\text { molecular weight } \\
\text { DNA }\end{array}$ & $\begin{array}{l}\text { Dominant } \\
\text { marker }\end{array}$ & & $\begin{array}{l}\text { No single } \\
\text { barcode } \\
\text { available to } \\
\text { distinguish all } \\
\text { plants }\end{array}$ \\
\hline & Time consuming & $\begin{array}{l}\text { Occurrence } \\
\text { of null } \\
\text { alleles }\end{array}$ & & & & \\
\hline & $\begin{array}{l}\text { Involves } \\
\text { radioactivity }\end{array}$ & & & & & \\
\hline
\end{tabular}

Source : *Adapted from Ganie et al. (2015) 
Limitations in the use of molecular markers: Molecular marker analysis involves cost and time. In many cases, significant polymorphism is not detected. Thus, it is not possible to apply them in all plants. Some of the limitations of different markers are listed below (Table1).

\section{DNA marker studies in medicinal trees}

The present paper reviews the application of different molecular markers in 11 commercially important medicinal trees of India (Table 2 ). These species are mainly sources from the forests, leading to a depletion of their genetic stocks in the natural conditions. Some of these species are destructively harvested as root bark or stem bark are the major parts used in medicinal preparations. Large scale cultivation of these species is also not very encouraging.

\subsection{Aegle marmelos L. Correa}

\subsubsection{Species description}

Aegle marmelos, a deciduous tree, is a small to moderate size growing to a height of 20-25 feet and girth of 3-4 feet. It is naturally distributed in India, Myanmar and Sri Lanka, invariably in dry deciduous forests and widely cultivated in Southeast Asia and Tropical Africa (Warrier et al., 2010). The bark is shallowly furrowed and corky, leaves are trifoliate and aromatic which the branches has long straight spines.

The sweet scented greenish white flowers are bisexual, nearly $2 \mathrm{~cm}$ wide and are borne in clusters. The calyx is shallow with five short sepals and is pubescent on the outside. The five petals are pale greenish white, oblong ovoid, blunt, thick and dotted with oil glands. It has numerous stamens which sometimes are coherent in bundles. It has oblong ovoid ovary which is slightly tapering, with wide axis, cells numerous (8-20), small circularly arranged with numerous ovules in each cell. The brown coloured fruits are $5-7.5 \mathrm{~cm}$ in diameter, having globose, oblong pyriform shape, the rind is gray or yellow coloured while the pulp is thick yellow, orange to brown in color having sweet taste. The numerous seeds have wooly hairs and are arranged in the cells that are enclosed by slimy transparent mucilage, (Morton, 1987; Mishra, 1999).

Table 2: Medicinal tree species in commercial demand sourced from tropical forests

\begin{tabular}{|c|l|l|l|c|}
\hline S. No. & Species & Trade name & Parts used & $\begin{array}{c}\text { Estimated } \\
\text { Demand } \\
\text { (MT/ Year) }\end{array}$ \\
\hline 1. & Aegle marmelos & $\begin{array}{l}\text { Bael, Bel, Bael, Belgiri, Bilva, } \\
\text { Vilvam }\end{array}$ & $\begin{array}{l}\text { Leaf, Fruits, Bark } \\
\text { (Root, Stem) }\end{array}$ & $2000-5000$ \\
\hline 2. & Commiphora wightii & Guggulu, Gugal & Gum resin & $1000-2000$ \\
\hline 3. & Emblica officinalis & Amla, Nelli Amalaki & Fruits & $>10000$ \\
\hline 4. & Gmelina arborea & Ghambar chal, Gambhari & Bark (Root) & $500-1000$ \\
\hline 5. & Oroxylum indicum & Tetuchaal, Syonaka & Bark (Stem, Root) & $500-1000$ \\
\hline 6. & Santalum album & Chandan, Sveta candana & Wood (Heartwood) & $500-1000$ \\
\hline 7. & Saraca asoca & Ashoka & Bark (Stem) & $1000-2000$ \\
\hline 8. & Stereospermum chelonoides & Patala, Padal fali, Patalai & Root & $500-1000$ \\
\hline 9. & Strychnos nux-vomica & Kuchla, Nirmali, Visamus & Fruits, Stem or Bark & $500-1000$ \\
\hline 10. & Terminalia arjuna & Arjun, Arjuna & Fruits, Bark (Stem) & $2000-5000$ \\
\hline 11. & Terminalia bellirica & Behdea, Bibhitaka & Fruits & Fruits \\
\hline 12. & Terminalia chebula & Harda, Haritaki & $2000-5000$ \\
\hline
\end{tabular}

Source: NMPB, 2018. https://www.nmpb.nic.in/medicinal_list

\subsubsection{Parts used and properties}

Roots, leaves and fruits are mainly used. The roots are sweet, astringent, bitter and febrifuge. They are useful in diarrhea, dyspepsia, dysentery, stomachalgia, cardiopalmus, uropathy, vitiated conditions of vata, seminal weakness, and swellings. The leaves are useful in diabetes and asthmatic complaints, deafness, catarrh, ophthalmia and inflammations. The unripe bael fruits are sour, acrid, bitter having astringent, digestive and stomachic properties. It is also used in diarrhea and dysentery. The ripe fruits are sweet, astringent, cooling, aromatic, laxative, febrifuge and tonic. It is good for heart, brain and dyspepsia (Warrier et al., 2002).

\subsubsection{Diversity}

PCR-based RAPD markers were first reported by Britto et al. (2009) assessing the genetic variability in ten genotypes of the species from the Western Ghats. Twenty nine polymorphic loci were obtained using five primers, suggesting the variability existing in the selections. These markers generated 476 polymorphic loci with $64 \%$ polymorphism in A. marmelos collected from the Andaman 
Islands (Nayak et al. 2013). Recently, a study conducted by Parvesh and Vijaya (2018) revealed that these markers are effective in distinguishing genotypes in the Chhattisgarh region also. This implies that RAPD markers could be used to efficiently manage germplasm collections of the species for future improvement programmes. RAPD markers could also detect the genetic uniformity in in vitro grown plants (Pati et al., 2008 a, b; Mishra et al., 2008). Four intersimple sequence repeats (ISSR) used to assess genetic variability among 18 A. marmelos genotypes, revealed 12 monomorphic bands (Mujeeb et al., 2017; Princy et al., 2015). Mishra et al. (2008) tested the genetic uniformity of regenerated plantlets and mother plants using directly amplified minisatellite DNA (DAMD) and ISSR markers. Microsatellite markers revealed $100 \%$ polymorphism in genotypes of A.marmelos (Sharma and Sharma, 2015). Chloroplast matK barcode has been identified as a unique barcode to distinguish the species from its adulterants (Sivalingam et al., 2016). The transcriptome analysis of the species revealed 1298 complete genes with an average of 2.03 orthologs/core gene (Kaushik and Kumar 2018). The gene QNS is identified as responsible for quinolone biosynthesis and conferring salt and drought tolerance (Resmi et al., 2013; 2015).

\subsection{Commiphora wightii (Arnott) Bhandari}

\subsubsection{Species description}

Commiphora wightii (Family Burseraceae) is a shrub or small tree, attaining maximum height of $4 \mathrm{~m}$. The bark is thin and papery and the branches are thorny. The leaves are simple or trifoliate, having ovate leaflets which are $1-5 \mathrm{~cm}$ long, $0.5-2.5 \mathrm{~cm}$ broad and is irregularly toothed. The small red to pink flowers are sessile, unisexual, occurring solitary or in groups of of 2-3, 8-10, having lobed disc, oblong-ovoid ovary with 8-10 stamens and four small petals. Some plants bear bisexual and male flowers and others with female flowers only. The red drupe fruits are ovate, acuminate and separating into two fleshy leaves and the nut is enveloped by a 23, 8-10 lobed disc and an oblong-ovoid ovary. The nuts are ovoid acute in shape, splitting into two each with one cell (Chaudhary et al., 2002)

\subsubsection{Parts used and properties}

The roots and leaves are used. Roots are astringent, sweet, cooling, aphrodisiac and diuretic. They are used in diabetes, strangury, fever and vitiated conditions of vata and pitta. The leaves are anodyne and used in rheumatalgia (Warrier et al., 2002).

\subsubsection{Diversity}

Samantaray et al. (2009) developed an efficient DNA extraction protocol and standardised the PCR reactions for the species. Hague et al., (2009 a, b) used ITS sequences to differentiate in $C$. wightii while three RAPD primers were observed to be associated with sex expression (Samantaray et al., 2010). Suthar et al. (2010) grouped different accessions of $C$. wightii genotypes collected from Rajasthan and Gujarat into three subgroups using RAPD markers. Harish et al. (2014) estimated genetic diversity within and among different 45 populations of $C$. wightii. Krishnamurthy et al. (2015) used 20 RAPD primers; Vyas and Joshi (2015) used 11 markers for diversity assessment of $C$. wightii populations in Rajasthan while Kulhari et al. (2015) used ISSR and RAPD to analyze genetic variability among C. wightii germplasm of Rajasthan and Haryana. Sairkar et al. (2016) developed four SCAR markers for rapid identification of closely related Commiphora species. Chaudhary et al. (2017) and Mohan et al. (2017) used fluorescent-labeled RAPD primers used for genetic analyses. Genetic diversity analysis conducted in $61 \mathrm{C}$. wightii accessions using 20 decamer primers revealed 121 out of 124 loci to be polymorphic. Bishoyi et al. (2018) has consolidated the application of different molecular markers in the discrimination Commiphora species distributed in India.

\subsection{Emblica officinalis Gaertn. (Phyllanthus emblica L.)}

\subsubsection{Species description}

Emblica officinalis (Family: Euphorbiaceae) is a moderate sized deciduous tree known as Amla or Emblic myrobalon. As it sheds branchlets as well as leaves, it is seldom entirely bare and, therefore sometimes mentioned as evergreen. The tree is found throughout tropical and sub-tropical India. The species is native to India and also grows in Pakistan, Uzbekistan, Sri Lanka, Bangladesh, Southeast Asia, China, and Malaysia (Krishnamurthy, 1993; Warrier et al., 2003). Being a graceful ornamental tree, it normally reaches height up to $18 \mathrm{~m}$ and in rare occasions reaching upto $30 \mathrm{~m}$. The pale grayish brown bark is fairly smooth and peels off in thin flakes. The small oblong leaves distichously disposed on very slender branchlets are $3 \mathrm{~mm}$ wide and $1.25-2.0 \mathrm{~cm}$ long. The small greenish yellow flowers found in the axils of the lower leaves are, inconspicuous and are borne in compact clusters. The female flowers are found above the male flowers that occur at the lower end of a growing branchlet. There are trees that are occasionally deciduous. Fruits are 1.5 to $2.5 \mathrm{~cm}$ in diameter, fleshy round rather indistinctly marked into 6 lobes. The skin is thin, translucent and adherent to the very crisp, juicy, concolorous flesh. There is a hexagonal stone which is tightly embedded in the center of the flesh containing 6 small seeds (Morton, 1987).

\subsubsection{Parts used and properties}

Amla is useful in treating anaemia, diarrhoea, dyspepsia, inflammation of eyes, and menorrhagia. It also finds use in medicinal preparations like chyawanprash and brahma rasayan, etc. The fruits are diuretic and laxative and are useful in digestive system disorders. They are also prescribed for treating jaundice and coughs. It is also one of the three important ingredients of Triphala, a famous ayurvedic preparation which is extensively used in treating biliousness, chronic dysentery, and other disorders. It is also known for its antiseptic properties and, therefore used for cleaning wounds and as a palliative for snake bites and scorpion stinging (Warrier $e t$ al., 1997).

\subsubsection{Diversity}

Isolation of genomic DNA from young leaf tissues of different commercial varieties of $P$. emblica was standardized by employing modified DNA extraction protocols (Singh, 2003). RAPD markers were used to distinguish varieties of aonla of same origin or even selection from same parents, suggesting its use in identification of varieties in crop improvement programme (Chaurasia, 2009). A 1.1 kb SCAR marker specific to $P$. emblica was developed from RAPD amplicons, useful for differentiating $P$. emblica from its adulterants (Dnyaneshwar et al., 2006). Similarly, eighty RAPD primers were screened to develop DNA based marker for identification of P. emblica and a SCAR marker of $1.1 \mathrm{~kb}$ specific to $P$. emblica was identified (Warude et al., 2006). Six microsatellite loci developed by Pandey and Changtragoon (2012) showed 
polymorphism in five primers with the number of alleles ranging from four to seven while 20 microsatellite markers generated by Geethika et al. (2018) revealed 2-9 alleles per locus. Four polymorphic SSR markers and one SCAR marker was used to understand diversity in 66 genotypes of $P$. emblica from different locations of Sri Lanka (Mawalagedera et al., 2015). Single nucleotide polymorphisms in trnl (UAA) intron sequences of chloroplast DNA was used as a potential marker to differentiate $P$. emblica from its allied species (Sangeetha et al., 2010). For understanding the genetic structure and gene flow, to identify novel genes of interest and for developing markers for assisted breeding, 20 EST-SSR primer pairs showing polymorphisms in 90 individuals from three populations were developed from the transcriptome of P. emblica (Liu et al., 2018).

\subsection{Gmelina arborea Roxb.ex Smith}

\subsubsection{Species description}

Gmelina arborea Roxb.ex Smith belongs to the family Verbenaceae, and is naturally distributed throughout India. It has been found and grown extensively in temperatures ranging from 1 to $48^{\circ} \mathrm{C}$ with annual rainfall varying from 760 to $4500 \mathrm{~mm}$ (Anandalakshmi et al., 2016). The pubescent or glabrous leaves are oppositedecussate, petioles are cylindrical with 50 to $150 \mathrm{~mm}$ long.

Leaf blades are broadly ovate, $10-25 \mathrm{~cm} \times 7-20 \mathrm{~cm}$ wide, and are apically long acuminate or caudate and is entire on mature plants. The reddish brown or yellow scented flowers are terminal or axillary having 1 to 3 cymes on the panicle branches which are about 8- 40 $\mathrm{cm}$ long. Flowers vary from 2.5 to $5 \mathrm{~cm}$ in diameter, bracts $8 \mathrm{~mm}$ long which is linear lanceolate. Calyx is broad, campanulate and 5 $\mathrm{mm}$ long densely fulvous tomentose externally having rim with five small, triangular acute teeth. The yellow to orange or brilliant orange to reddish or brownish-yellow, dull yellow-brown corolla is large, tubular below, obliquely funnel-form at the throat, the limb is two lipped and the upper lip often orange-pink in colour is deeply divided into two oblong, obtuse backwardly curled lobules. The lower lip is three lobed often lemon yellow in colour and is twice longer than the upper lip. The fruit is a drupe, long obovoid shaped and 20 to $35 \mathrm{~mm}$ long. It is seated on the enlarged calyx and the ripened fruit is glossy yellow in colour. The exocarp is succulent and aromatic while the two celled endocarp is bony having 1 to 3 seeds (Mayavel and Nicodemus, 2017).

\subsubsection{Parts used and properties}

The roots are acrid, bitter, sweet, stomachic, tonic, laxative, galactagogue and anthelmintic. It is useful in dyspepsia, hyperdipsia, hallucination, fever, haenonhoids, stomachalgia and burning sensation. Leaf paste is good for cephalalgia and the juice of the leaf is useful in washing foul ulcers. The flowers are sweet, refrigerant, bitter, astringent and acrid, and are used in treating skin diseases and leprosy. They are used for anaemia: leprosy, ulcers, constipation, strangury, leucorrhea and colpitis (Warrier, 1993).

\subsubsection{Diversity}

A modified protocol for isolating DNA from dried leaves of Gmelina arborea, suitable for further molecular analysis was developed by Shankar and group (2009). Genetic diversity was analysed using Inter-simple sequence repeat (ISSR) primers. 95\% polymorphic loci was obtained among eight populations (Naik et al., 2009).
Genetic diversity of $G$. arborea $(\mathrm{n}=534)$ was evaluated using ten polymorphic microsatellite markers for 19 natural populations representing India, China, Thailand and Myanmar (Wee et al., 2011).

\subsection{Oroxylum indicum (L.) Kurz.}

\subsubsection{Species description}

It is a deciduous tree which is small or medium in size, growing to a height of $12 \mathrm{~m}$. The bark is soft, light brown or grayish brown in colour having corky lenticels. The large glabrous leaflets are ovate or elliptic, acuminate in shape and are 90 to $180 \mathrm{~cm}$ long having 23 pinnate with five or more pairs of primary pinnae which are cylindrical and swollen at the junction of branches. The withered and fallen large leaf stalks get collected near the base of the trunk and appear as a pile of broken limb bones. The plant flowers in June-July and bears fruits in November. The numerous reddish purple flowers have pale pinkish-yellow colour inside and forms a large erect raceme. The nocturnal blooming flowers attracts bats as it emit a strong stinky odour. The long curved fruit pods hang down from the branches and resemble the wings of a large bird or appear like a dangling sickles or swords. These pods are 40 to $100 \mathrm{~cm}$ long and 5 to $10 \mathrm{~cm}$ broad. The dried pods burst open resulting in fluttering of numerous seeds on the ground. Sometimes, these thin papery winged seeds are carried by wind for some distance which resembles as though butterflies are flying (Kirtikar and Basu, 2001; Warrier et al., 2016).

\subsubsection{Parts used and properties}

The root bark is bitter, pungent, acrid, astringent to the bowels, increases appetite, cooling, aphrodisiac, useful in "vata. It is also used in treating fevers, vomiting, intestinal worms, dysentery, leucoderma, bronchitis, asthma and anal troubles (Warrier et al., 1995).

\subsubsection{Diversity}

In a study carried out in Andhra Pradesh to assess genetic diversity from eight locations, forty RAPD primers were used. It showed high levels of similarity (Jayaram and Prasad, 2008), revealing a very narrow genetic base while ISSR markers used for assessing the genetic diversity and population genetic structure of 39 accessions of belonging to South and North East India, showed high genetic diversity among populations but low within population variation (Rajasekaran et al., 2017). In a similar study, Aparna and Srinivas (2018) reposted the same trend with accessions from Maharashtra and North East India. Both studies revealed clear differentiation between the Western Ghats and North East Indian populations. The only other marker study reported in the species is the assessment of clonal fidelity of in vitro regenerated plants (Gokhale and Bansal, 2015; Rami and Patel, 2017; Panchaksharaiah et al., 2018).

\subsection{Santalum album $\mathrm{L}$.}

\subsubsection{Species description}

This species is native to India, Sri Lanka and Indonesia. In India, the natural distribution of the species is Karnataka, Tamil Nadu, Andhra Pradesh and Kerala states; the species is introduced to other parts of India (Arunkumar et al., 2012). In its natural habitat, subpopulations are not dense, devoid of larger girth classes and mature trees are entirely or nearly absent in the forest areas of 
Karnataka and Tamil Nadu (Arunkumar et al., 2019). It is a moderate sized evergreen tree attaining a girth of 1 to $2.4 \mathrm{~m}$ and height of 12 to $15 \mathrm{~m}$ (Sen Sarma, 1982).

The bark is found to be smooth when the tree is young and gradually as the tree matures, becomes rough by developing vertical cracks. The inner part of the bark is red in colour. The flowers are straw yellow coloured initially which turn to deep purplish brown as they mature. The flowers which occur axillary or terminal as cymose panicles are shorter than leaves and the floral organs develop in acropetal succession. The time required from initiation of bud stage to anthesis is around 30 to 35 days, while it takes 85 to 95 days for ripening of the fruit from the initial stage (Srinivasan et al 1992). The fruit is a drupe, initially green in colour and gradually when fully matured becomes succulent and purplish black. The fruit shape varies from globose, ovate to elongate and sometimes show tapering ends (Arunkumar et al., 2016).

\subsubsection{Parts used and properties}

The yellow coloured heartwood is bitter, sweet, acrid, cardiotonic, diuretic, expectorant, antipyretic, haemostatic, diaphoretic, aphrodisiac, anodyne, aromatic, deodorant, refrigerant, restorative and intellect promoting tonic, useful when pitta condition is vitiated, foul odour due to hyperhidrosis, leprosy, forgetfulness, amentia, cardiac debility, jaundice, skin disease, inflammations, bronchitis and cough, gastric irritability, leucorrhoea, spermatorrhoea, general debility (Warrier et al., 1996).

\subsubsection{Diversity}

Significant amount of genetic diversity among natural sandalwood populations has been reported in sandalwood (Arunkumar et al., 2012). Using allozyme markers, genetic diversity of different sandal populations in peninsular India was studied and results indicated that populations found in Deccan plateau were genetically the most diverse and, thereby representing the 'hot-spot' of sandalwood genetic resources in peninsular India (Angadi et al., 2003; Rao, 2004; Rao et al., 2007). Clones selected based on growth and oil content, in the states of Karnataka and Tamil Nadu when subjected to isozyme studies, provided information about the relative amounts of genetic variation existing within sandalwood accessions (Arunkumar et al., 2018).

Genetic diversity of sandal was assessed using RAPD markers (Shashidhara et al., 2003; Suma and Balasundaran, 2004; Azeez et al., 2009; Dani et al., 2011). Patel et al. (2016) characterized 20 sandalwood genotypes using RAPD, ISSR and SSR markers and found high level of genetic diversity and correlation among all markers. Genetic diversity of S. album using SSRs in 177 genotypes from 14 populations of three states (Karnataka, Telangana and Kerala) revealed that the populations were admixtures (Fatima et al., 2019). Mohammed et al. (2012) used SSR markers to understand their applications through cross-transferability while and restriction fragment length polymorphism (RFLP) was used for regional differentiation (Byrne et al., 2003). Chloroplast RFLPs were employed to identify ancestral lineages and determine whether Indonesian $S$. album is genetically distinct from Indian material (Jones et al., 2009). Due to the range of the species, it is anticipated that there is high genetic variability but more studies are needed to confirm the extent of variation (Thomson et al., 2018).

\subsection{Saraca asoca (Roxb.) de Wilde.}

\subsubsection{Species description}

Saraca asoca (Roxb.) de Wilde. belongs to the family Fabaceae, sub family Caesalpinioideae. The species is native of South India, Bangladesh and Western Myanmar; distributed in the Central and Eastern Himalayas, Khasi, Garo and Lushi hills, North eastern states of India, West Bengal, Orissa and in Western Ghats (Singh et al., 2005a). It is a small, under storey evergreen tree growing up to a height of $10 \mathrm{~m}$ and has an average diameter of $20-30 \mathrm{~cm}$. It has a blackish bark with reddish wood, found mostly along streams or under the shade of large evergreen patches of forests (Singh et al., 2005b). The canopy is dense and the branches are somewhat droopy bear nearly sessile, large, abruptly pinnate leaves, $20-40 \mathrm{~cm}$ long, having 3-6 pairs of large oblong lanceolate leaflets, $8-16 \mathrm{~cm}$ long. The tender leaves are copper coloured and they resemble ponytail. Flowers are fragrant, large, snowy and yellow to orange in colour changes to red gradually and are borne in dense corymbose inflorescence. The pods are flat, leathery $15-30 \mathrm{~cm}$ long $2-5 \mathrm{~cm}$ wide, green when immature and turning to brown when the seeds are mature. Each pod contains 4-8 seeds, which are ellipsoid oblong and compressed with brown smooth seed coat and white cotyledons (Warrier et al., 2007).

\subsubsection{Parts used and properties}

Bark is the main component used. The bark extract has been reported to possess a variety of therapeutic effects (Singh et al., 2015). The bark is bitter, sweet, astringent, refrigerant, stomachic, anthelmintic, demulcent, constipating and demulcent. It is used in fever, dipisa, dyspepsia, burning sensation, colic ulcers, menorrhagia, leccorrhoea, metropathy and pimples. The flowers are used in vitiated conditions of pitta, considered to be uterine tonic, treated in syphilis, burning sensation, dysentery, inflammation and scabies in children, haemorrhoids, cervical adenitis and hyperdipsia. The dried flowers are used in treating haemorrhagic dysentery and diabetes. Seeds are used for stangury and vesical calculi and treating bone fractures (Warrier et al., 1996).

\subsubsection{Diversity studies}

Numerous authors have worked on molecular markers in Saraca asoca. They include RAPDs, ISSRs, AFLPs, SCARs and DNA barcodes. The major focus of these studies were analyzing genetic variability and diversity, species authentication and detecting adulteration. DNA isolation and PCR protocol for RAPD for Saraca asoca was developed by Padmalatha and Prasad (2006). RAPD markers were used to study genetic variations in five different populations in Orissa (Senapati et al., 2012); while Shrivastava et al. (2015) used 10 ISSRs, 9 AFLP primer and 5 SSRs to assess the genetic diversity in four natural populations in Orissa. All the SSR and AFLP markers revealed the existence of very narrow genetic base among the studied populations while RAPDs and ISSRs revealed high polymorphism, which could be attributable to the dominant nature of the markers. Recently, Saini et al. (2018) studied genetic diversity in S. asoca trees in seven different forest areas and three cultivated sites located in central and north-central Western Ghats using RAPD markers. The within population variation was higher (89\%) than among population diversity $(11 \%)$, suggesting good natural crosspollination. As a modification, fluorescent-labelled RAPD primers were used to assess genetic diversity in individual trees from different 
locations in Andhra Pradesh (Mohan et al., 2017). RAPD markers produced distinct banding patterns to distinguish $S$. asoca from its common adulterant Polyalthia longfolia (Gahlaut et al., 2013). Seventeen populations from Karnataka were assessed using 8 ISSR markers (Rosario, 2015). Populations growing in suitable habitats possessed high polymorphism. The within population variation was higher $(82 \%)$ than among population diversity (18\%). Microsatellite markers have also been developed for diversity analysis in this species (Sumangala et al., 2013). Saraca specific SCAR markers with an amplicon length of 193 bp has been developed for identification and discrimination of Saraca from its adulterants (Kumar, 2016). AFLP analysis coupled with HPTLC fingerprinting revealed that chemical fingerprinting has proved as the better classifier than genetic markers in distinguishing species (Sharma et al., 2018). Chloroplast matK barcode has been used to understand the evolutionary and phylogenetic relationship of $S$. asoca with other members present in the tribe Detariae (Saha et al., 2013). DNA barcoding coupled with RP-HPLC (Hegde et al., 2017) and NMR spectroscopy (Urumarudappa et al., 2016) was successful in differentiating crude bark samples of $S$. asoca from its adulterants. The barcodes were generated from rbcL and psbA-trnH.

Hegde (2018) coupled ISSR fingerprints and rbcL-based DNA barcodes to differentiate common adulterants and substituents of $S$. asoca. Samples from six different states that consisted of ten localities revealed $47.06 \%$ polymorphism.

\subsection{Stereospermum chelonoides (L. fil.) DC.}

\subsubsection{Species description}

S. chelonoides (L. fil.) DC. is a large deciduous trees with large straight stem reaching a height of about 18 to $30 \mathrm{~m}$ and $2.8 \mathrm{~m}$ girth. It is found extensively in the moist regions of deciduous forests of India, reaching up to an altitude of about $1200 \mathrm{~m}$ (Parrota, 2001). It is commonly found in India, Myanmar, Sri Lanka; in the Western Ghats South, Central and South Maharashtra Sahyadris, commonly known as Yellow snake tree. The imparipinnate compound leaves are opposite, decussate and the rachis which is canaliculated and glabrous are 6 to $16.5 \mathrm{~cm}$ long. The leaflets are 3-5 pairs, opposite with odd terminal one. The petiole which is 0.8 to $1.5 \mathrm{~cm}$ long, the elliptic lamina 5 to $15 \times 2.5-7.5 \mathrm{~cm}$, having caudate apex and cuneate base with entire margin, glabrous, characeous, mid rib being flat above, and the secondary nerves which are 8 to 10 pairs gradually curved whereas the tertiary nerves are weakly precurrent.

\subsubsection{Parts used and properties}

Every part of the tree is used in treating many disorders. The leaves are used to treat wounds, malarial fever, otalagia, rehumatalgia and odantalgia. The decoction of the leaves is used to treat chronic dyspepsia and as antipyretic. The root which forms one of the ten ingredients in 'Dasamula' an Ayurvedic formulation is bitter astringent and acrid.

It is used such as cardio tonic, appetizer, diuretic, anodyne, aphrodisiac, lithotropic, antiinflammatory, antibacterial, anticancer, febrifuge tonic, antiemetic, antipyretic. The root decoction is used to treat cough and asthma (Warrier, 2002).

\subsubsection{Diversity}

No reports on DNA marker studies are available.

\subsection{Strychnos nux-vomica Linn.}

\subsubsection{Species description}

Strychnos nux-vomica Linn. (Loganiaceae) is an important medicinal plant, native to Southeast Asia, especially India and Myanmar (American Cancer Society, 2000). It is a medium sized deciduous tree which is found naturally on wastelands and is found in degraded forests of West Coast and in Western and Eastern Ghats of India (Sivakumar et al., 2006). Branches are irregular and covered with smooth ash colored bark and shiny dark green young shoots. The greenish white coloured flower occurs as terminal cymes, appearing with young leaves on axillary shoots or at the end of branchlets. The hermaphrodite funnel shaped flowers are small in size, nectariferous and emits unpleasant odour. The pentamerous flowers have ovate calyx lobes having dense hair outside. Corolla is slender tube of $1 \mathrm{~cm}$ long, widening at the throat abruptly, glabrous outside having pubescence at base, narrowly ovate greenish white to white lobes are $3 \mathrm{~mm}$ long, having thickened margin and minute hairs. The stamens are inserted at the mouth of the corolla and the tubes alter with corolla lobes. Pale cream coloured anthers are dithecous, introrse and dehisce longitudinally. The bicarpellary ovoid ovary is superior, glabrous and with axile placentation. The style is filiform and similar in length to that of corolla tube with head shaped stigma. The ellipsoid or orbicular lens shaped seeds are covered with dense silky hairs that radiate from the centre which results in providing a characteristic shine to the seed. The seed is concave on one side and the other side, it is convex, having a small depression in the centre of either side. The hard endosperm is dark grey in colour, bitter in taste, odourless and contain small embryo (Schmelzer and GuribFakim, 2013; Patel et al., 2017; Behera et al., 2017).

\subsubsection{Parts used and properties}

As recommended by the Ayurvedic Pharmacopoeia of India, the detoxified seeds are used in treating facial paralysis, sciatic and impotency (Kirtikar and Basu, 1991). The bark of the root is useful in intermittent fever, cholera and snake bite. The poultice made out of the leaves, is used in treatment of chronic wound and ulcers. The fruit pulp is used in treating paralytic affections of palms and foot. The bitter seeds are used as digestive, appetizer, antiperiodic, aphrodisiac and stimulant. They are applied to treat anemia, skin disease, bronchitis, asthma, malarial fever, diabetes, muscle weakness, colic, chronic constipation, insomnia, mental emotions, hysteria, paralysis, emphysema, nervous debility, gout, chronic rheumatism, hydrophobia and spermatorrhoea (Warrier et al., 1993). Apart from medicinal use, it is also a rodenticide, avicide, insecticide, mematicide and piscicide (Behera et al., 2017).

\subsubsection{Diversity}

No reports on DNA marker studies are available.

\subsection{Terminalias (Terminalia arjuna (Roxb.) Wight \& Arn.,} T. bellirica (Gaertn.) Roxb., T.chebula (Gaertn.) Roxb.)

\subsubsection{Species description}

Terminalia arjuna: A native of the Indian subcontinent, T. arjuna is found eastwards in Myanmar and southwards in Sri Lanka also. Being a riparian species, it occurs along the river banks and streams in South and North India. A large deciduous trees which reaches a height of $30 \mathrm{~m}$ and a girth of 2 to $2.5 \mathrm{~m}$ having a buttressed trunk. The crown spread is large with drooping branches. The grey or 
pinkish-green bark is smooth, thick and exfoliating in think irregular sheets. The oblong or elliptically oblong shaped simple leaves are opposite to sub-opposite, $5-25 \times 4-9 \mathrm{~cm}$ in length and width, is glabrous, hard and often inequilateral. The leaf apex is obtuse or sub-acute having round base or sometimes cordate. The short petiole is 2-4 cm long is sericeous and has two prominent glands at the apex of the petiole. The inflorescence is short axillary spikes or small terminal panicles, $9-13 \mathrm{~cm}$ long with 2.5 to $6 \mathrm{~cm}$ branches. The short rachis is pubescent and white in colour. The white, creamy or greenish-white coloured cup shaped flowers are small, regular, polygamous, sessile and strongly honey scented. Fruits are indehiscent drupe, dark brown to reddish brown coloured, obovoidoblong shaped 2.5-6 $\times 1.8-2.8 \mathrm{~cm}$ long, glabrous with 5-7 equal thick narrow stiff-wings which are striated having numerous upwards-curved veins (Orwa et al., 2009).

Terminalia bellirica occurs most frequently in the moist valleys and not in arid regions. The tree populations are distributed throughout the forests of India, below elevations of about $3000 \mathrm{ft}$. It mostly represents scattered populations. The large leaves are alternate, glabrous, broadly elliptic to obovate-elliptical, 4-24 cm x $2-11 \mathrm{~cm}$. The base is rounded to cuneate, rufous-sericeous but soon glabrescent, with 6-9 pairs of secondary veins. The secondary and tertiary venation is prominently found on both the leaf surfaces. The petiole is 2.5 to $9 \mathrm{~cm}$ long. The young leaves are copper red in colour which soon changes into parrot green and then to dark green. The solitary greenish white, simple flowers are small $3-15 \mathrm{~cm}$ long, having axillary spikes. The calyx tube is densely sericeous or tomentulose. The flowers are found along with new leaves and have a strong honey like smell. The sub-globular to broadly ellipsoid fruits is light yellow in colour, densely velutinous or sericeous, 2$4 \times 1.8-2.2 \mathrm{~cm}$. It is obscurely five angled and minutely brown tomentose.

Terminalia chebula: It is found in the sub-Himalayan tracts from the river Ravi eastwards upto West Bengal and Assam, ascending upto an altitude of $1,500 \mathrm{~m}$ in the Himalayas, in deciduous and moist forests, West Coasts and hills of Deccan and South India. The deciduous tree reaches $25 \mathrm{~m}$ tall. The dark brown to black coloured bark is 5 to $6 \mathrm{~mm}$ thick having shallow vertical fissures which is exfoliating in thick scales. When blazed, has yellowish brown colour. The young shoots are densely pubescent and the glabrous branchlets are brownish or grayish in colour. The simple leaves are opposite to alternate, exstipulate. The stout and pubescent petiole is $12-25 \mathrm{~mm}$ long, grooved above, having two sessile glands at the top. The leaf lamina is $9.5-28 \times 4-13 \mathrm{~cm}$ long and wide, and is ovate, elliptic, obovate or elliptic-obovate in shape with base being round, obtuse, oblique or subtruncate, the leaf apex is acuminate, obtuse or apiculate, margin is entire, coriaceous, glabrous above tawny villous beneath, lateral nerves 6-12 pairs, pinnate, ascending, prominent, arched towards the margin. The bisexual flowers are greenish white in colour as terminal and axillary spikes having offensive smell. The bracts are 2-3 $\mathrm{mm}$ long with calyx tube which is constricted above the ovary is $1.5-2.5 \times 0.8-1 \mathrm{~mm}$, having five lobes which is creamy and triangular. The ten stamens are in two rows, with filaments $4-6 \mathrm{~mm}$ and five lobed discs. The inferior ovary is densely villous, one celled with terminal stigma. Fruit is a greenish-yellow drupe 3-4 × 2-2.5 cm, obovoid, woody, obscurely 5 angled, glabrous, having one seed.

\subsubsection{Parts used and properties}

T. arjuna: Bark has medicinal properties like astringent, antioxidant, aphrodisiac, cooling, tumors, ulcers, diabetes, leucorrhoea, spermatorrhae, in fractures, cough, asthma, excessive perspiration and skin related problems (Warrier, 1994).

T.bellirica: Fruits, roots and leaves have medicinal properties. It is used in Ayurveda and Sidda for constipation, chronic diarrhoea, ulcer, gastroenteritis, asthma, cough, dyspnea, dyspepsia, hemorrhoids, malabsorption syndrome, parasites, candidiasis, hepatomegaly, renal calculi, urinary discharge, tumours, skin disease, memory loss, epilepsy, diabetes, cardiovasular disease, anorexia and wounds (Nadkarni, 1976).

T. chebula: Unripe fruits are used as purgative, ripe fruits are more astringent, antibilious and stomachic. It is prescribed for treating diarrhea, dysentery, constipation and flatulence, vomiting, digestive disorders, cyst, enlarged liver and spleen, bronchial asthma and cough and for metabolic harmony. Bark is diuretic (Warrier, 2002).

\subsubsection{Diversity}

Diversity DNA isolation from leaves of Terminalia species is cumbersome due to high amount of carbohydrates precipitated with DNA (Sarwat et al., 2006; Deshmukh, 2007; Sairkar et al., 2013; Bharti, 2018). Warude et al. (2003) standardized DNA extraction protocol for RAPD based identification of Terminalia bellerica and T. chebula. A common protocol was developed for the isolation of genomic DNA from different tree species of Combretaceae family (Gupta et al., 2011). Dangi et al. (2011) reported variations in 28 accessions of Terminalia bellerica based on RAPD markers. Gowda et al. (2012) estimated genetic diversity and relatedness among Terminalia chebula trees from five provenances of Karnataka using RAPD markers while Sankanur (2013) used twenty five RAPD and twelve ISSR primers to reval revealing polymorphism in the species from the same region. In T.arjuna, low genetic diversity was recorded in the germplasm of Madhya Pradesh (Sairkar et al., 2017) RAPD markers have also been used to diagnose genetic diversity and species relationship among T. arjuna, T. bellirica, T. chebula, T. tomentosa and T. catappa. RAPD markers clustered T. arjuna, T. bellirica, T. chebula in one group and the remaining two species were clustered together in another group (Deshmukh et al., 2009). Further, genetic diversity and species correlation using AFLP, ISSR and RAPD clustered these three species in three different groups (Sarwat et al., 2011a, b).

To assess genetic diversity and species relationships of five taxonomically critical Terminalia species, 31 random primers were used. Among these primers, 26 primers amplified across all species with 90 per cent of the bands polymorphic. Each primer on an averaged scored 12.92 bands. The dendrogram showed that the five Terminalias were grouped into two distinct clusters (Deshmukh et al., 2009).

Studies using chloroplast DNA barcodes (rbcL, matK, and trnHpsbA) and a nuclear DNA barcode (ITS2) for species identification by Nithaniyal and Parani (2016) revealed that trnH-psbA was the best marker for species identification in Terminalias. With regard to species relationship studies, ITS2 was found to be better. However, Sharma and Shrivastava (2016) used internal transcribed spacer (ITS) regions to ascertain the identity of T. arjuna as well as detection of mixing of T. bellirica and T. chebula. A similar result 
was obtained by Mishra et al. (2017), who used rbcL, matK, ITS and psbAtrnH. They report that combination of matK+ITS to be an ideal barcode to differentiate Terminalias.

\section{Conclusion}

A global shift from illness care to wellness care is driving growth in foods as medicine. The demand for Ayurvedic products and traditional medicines is also putting pressure on the indigenous Ayurvedic industry which is witnessing higher demand for crude drugs. The total estimated market size of Indian Ayurveda industry products is US $\$ 2.27$ billion and is envisioned to grow to reach US $\$ 9$ billion by the year 2022 (CII, 2017; 2018). Given this scenario, there is a need to encourage and support small-scale cultivation of herbs in the rural regions, which would also open employment opportunities for youth. Mass cultivation of medicinal herbs is a potential market in the future. This will also help the industry for a sustainable collection of raw materials.

Medicinal plants can be prioritized as : (i) with high export potential, (ii) required for manufacture of classical formulations, and (iii) required in proprietary medicines. Species mentioned in this article fall into category two, and need to be brought from the wild to cultivated status to prevent depletion of these resources. The demand and supply situation for these bioresources will see drastic changes. It would be wise to prepare for this change, by adopting and evolving a workable formula in consultation with stake holders and regulators which would be beneficial to them and also help promote development of the herbal medicine industry. It would also supplement the cause of sustainable utilization of these bioresources promoting conservation alongside.

\section{Conflict of interest}

The authors declare that no conflict of interest exists in the course of conducting this research. All authors had final decision regarding the manuscript and the decision to submit the findings for publication.

\section{References}

American Cancer Society (2000). American Cancer Society's complete guide to complementary and alternative methods. American Cancer Society, Atlanta, U.S.A., pp:438.

Anandalakshmi, R.; Geetha, S.; Gurudev Singh, Sivakumar, V. and Warrier, R.R. (2016). Effect of fruit maturity stages on the germination and storage behavior of Gmelina arborea. My Forest, 52(1-4):69-76.

Angadi, V.G.; Jain, S.H. and Shankaranarayana, K.H. (2003). Genetic diversity between sandal populations of different provenances in India. Sandalwood Res. Newslett., 17:4-5.

Anon (2002). Centre for Research, P. and A. (New D., India), India. Dept. of Indian Systems of Medicine and Homoeopathy, and World Health Organization. Demand Study for Selected Medicinal Plants: Plant Profile, pp:208.

Aparna, A.S. and Srinivas, K.S. (2018). Genetic diversity analysis of Oroxylum indicum (L) Vent: An endangered and important medicinal plant using inter simple sequence repeat (ISSR) markers. Int. J. Bot. Studies, 3(3):78-81.

Arunkumar, A. N.; Warrier, R.R.; Shanthi, A. and Joshi, G. (2018). Allozyme variations to measure genetic diversity in clonal accessions of Indian sandalwood (Santalum album). Int. J. For. Hort., 4(1):1-8.

Arunkumar, A. N.; Joshi, G. and Warrier, R.R. (2016). Know Your Trees : Santalum album (Indian sandalwood). Van Vigyan ENVIS Newsletter, 2(4):2-11.
Arunkumar, A.N.; Dhyani, A. and Joshi, G. (2019). Santalum album. The IUCN Red List of Threatened Species 2019: e.T31852A2807668. http://dx.doi.org/10.2305/IUCN.UK.2019-1.RLTS.T31852A280 7668.en

Arunkumar, A.N.; Joshi, G. and Mohan Ram, H.Y. (2012). Sandalwood: History, uses, present status and the future. Curr. Sci., 103:1408-1416.

Azeez, S. A.; Nelson, R.; Prasadbabu, A. and Rao, M.S. (2009). Genetic diversity of Santalum album using random amplified polymorphic DNAs. Afr. J. Biotech., 8(13):2943-2947.

Bahulikar, R.A.; Lagu, M.D.; Kulkarni, B.G.; Pandit, S.S.; Suresh, H.S.; Rao, M.K.V.; Ranjekar, P.K. and Gupta, V.S. (2004). Genetic diversity among spatially isolated populations of Eurya nitida Korth. (Theaceae) based on inter-simple sequence repeats. Curr. Sci., 86:824-831.

Barrett, S.R.H.; and Kohn, J. (1991). Genetic and evolutionary consequences of small population size in plants: Implications for conservation. In: Genetics and conservation of rare plants (Ed. Falk, D.A. and Holsinger, K.E.) New York: Oxford University Press, pp:3-30.

Behera, M.C.; Mohanty, T.L. and Paramanik, B.K. (2017). Silvics, phytochemistry and ethnopharmacy of endangered poison nut tree (Strychnos nux-vomica L.): A review. J. Pharma. Phytochem., 6(5):1207-1216.

Biradar, D.P. (2015). Medicinal plants and phytomedicines. Ann.Phytomed., 4(1):1-5.

Bishoyi, A.K.; Kavane, A.; Sharma, A.; Geetha, K.A. and Samantaray, S. (2018). Molecular marker based discrimination study of Commiphora species distributed in India. Proc. Natl. Acad. Sci., India, Sect. B Biol. Sci., 88(4):1597-1604.

Bodare, S.; Tsuda, Y.; Ravikanth, G.; Uma Shaanker, R. and Lascoux, M. (2013). Genetic structure and demographic history of the endangered tree species Dysoxylum malabaricum (Meliaceae) in Western Ghats, India: Implications for conservation in a biodiversity hotspot. Eco. Evol., 3:3233-3248.

Bode, M. (2004). Ayurvedic and Unani Health and Beauty Products Reworking India's Medical Traditions. Ph.D. Thesis. Amsterdam Institute for Social Science Research, University of Amsterdam.

Boqian, Y.; Jing, W.; Guopei, C. and Ting, W. (2009). Isolation and characterization of polymorphic microsatellite loci in a traditional Chinese medicinal plant, Schisandra sphenanthera. Conserv. Genet., 10:615-617.

Britto, A.J.D.; Mahesh, R.; Sujin, R.M. and Dharmar, K. (2009). Detection of DNA polymorphism by RAPD-PCR fingerprint in Plumbago zeylanica L. from Western ghats. Madras Agricultural Journal, 96:291-292.

Britto, John de. R.; Mahesh, R. and Mary Sujin. (2009). Molecular characterization of Aegle marmelos (L.) Correa ex Roxb. Using RAPD markers. J. Swamy. Bot. Cl., 26:27-32.

Byrne, M.; MacDonald, B.; Broadhurst, L. and Brand J.E. (2003). Regional genetic differentiation in western Australian sandalwood (Santalum spicatum) as revealed by nuclear RFLP analysis. Theor. Appl. Genet., 107:1208-1214.

Cao, H.; But, P.P.H. and Shaw, P.C. (1996). Authentication of Chinese drug 'Ku-di-dan' (Herba elephantopi) and its substitutes using random primed polymerase chain reaction (PCR). Acta. Pharm. Sin., 31: 543-553.

Cao, H.; But, P.P.H. and Shaw, P.C. (1997). Identification of Herba taraxaci and its adulterants in Hong kong market by DNA fingerprinting with random primer PCR. Chin. J. Chin. Mater. Med., 22:197-200.

Chandramohan, A.; Divya, S.R. and Dhanarajan, M.S. (2013). Matk gene based molecular characterization of medicinal plant-Croton bonplandianum Baill. Int. J. Biosci. Res., 2:1-7. 
Chaudhary, G. (2012). Pharmacological properties of Commiphora wightii Arn. Bhandari : An overview, Int. J. Pharma. Pharmaceu. Sci. 4(3):73-75.

Chaurasia, A. K.; Subramaniam, V. R.; Krishna, B. and Sane, P. V.(2009). RAPD based genetic variability among cultivated varieties of Aonla (Indian Gooseberry, Phyllanthus emblica L.). Physiol. Mol. Biol. Plants, 15(2):169-173.

Chavan, P.; Warude, D.; Joshi, K. and Patwardhan, B. (2008). Development of SCAR (Sequence-charaterized amplified region) markers as a complementary tool for identification of ginger from crude drugs and multicomponent formulations. Biotech. Appl. Biochem., 50: 61-69.

Choudhary, M., Reddy, M.S., Kumar, M. and Devi, P.C. (2017). Genetic similarity studies of Commiphora wightii accessions by fluorescent-labeled RAPD primers. International J. Biotech. Biochem., 13:55-66.

Chun, S.; Jian-He, W.; Shi-Lin, C.; Huai-Qiong, C. and Cheng-Min, Y. (2009). Development of genomic SSR and potential EST-SSR markers in Bupleurum chinense DC. African J. Biotechnol., 8:6233-6240.

Confederation of Indian Industry (CII) (2017). Vision 2022 Roadmap for Indian Ayurveda Industry.https://ww2.frost.com/files/4815/1487/ 6125/FS_WP_CII_India_ Ayurveda_Industry_Road_ Map_ 101417_CAM-v4-Edited_Final.pdf.

Confederation of Indian Industry (CII) (2018). Ayurveda Industry Market Size, Strength and Way Forward, pp:52.

Dangi, B.; Jain, R.; Kachhwaha, S. and Kothari, S.L. (2012). Assessment of diversity in Terminalia bellerica Roxb.using morphological, phytochemical and molecular markers. Nat. Acad. Sci. Lett., 35 (1):135-144

Dani, K.G.S.; Ravikumar, P.; Pravinkumar, R. and Kush, A. (2011). Genetic variation within and among small isolated populations of Santalum album. Biol Plant., 55:323-326.

Datwyler, S.L. and Weiblen, G.D. (2006). Genetic variation in hemp and marijuana (Cannabis sativa L.) according to amplified fragment length polymorphisms. J. Forensic Sci., 51:371-375.

Deshmukh, V.P. (2007). A simple method for isolation of genomic DNA from fresh and dry leaves of Terminalia arjuna ( Roxb .) Wight and Argot. Electronic J. Bot., 10:468-472.

Deshmukh, V.P.; Thakare, P.V.; Chaudhari, U.S., Gawande, P.A. and Undal, V.S. (2009). Assessment of genetic diversity among Terminalia species using RAPD markers. Global J. Biotechnol. Biochem., 4(2):7074.

Devaiah, K., Balusubramani, S.P. and Venkatasubramanian, P. (2010) Development of randomly amplified polymorphic DNA based SCAR marker for identification of Ipomoea mauritiana Jacq (Convolvulaceae). Evid. Based Complement, Alternate Med., pp:1-7. doi:10.1093/ecam/neq023.

Devaiah, K.M. and Venkatasubramaniam, P. (2008). Development of SCAR marker for authentication of Pueraria tuberosa (Roxb.ex.Willd) Dc. Curr. Sci., 94:1306-1309.

Dnyaneshwar, W.; Preeti, C.; Kalpana, J. and Bhushan, P. (2006). Development and application of RAPD-SCAR marker for identification of Phyllanthus emblica LINN. Biol. Pharm. Bull., 29(11):2313-2316.

Do, H.D.K.; Jung, J.; Hyun, J.; Yoon, SJ.; Lim, C.; Park, K. and Kim, J.H. (2019). The newly developed single nucleotide polymorphism (SNP) markers for a potentially medicinal plant, Crepidiastrum denticulatum (Asteraceae), inferred from complete chloroplast genome data. Mol. Biol. Rep., 46(3):3287-3297.

Enan, M.R. and Ahamed, A. (2014). DNA barcoding based on plastidmatK and RNA polymerase for assessing the genetic identity of date (Phoenix dactylifera L.) cultivars. Genet. Mol.Res., 13:35273536 .
Fan, W.J.; Luo, Y.M.; Li, X.X.; Gu, S.; Xie, M.L.; He, J.; Cai, W.T. and Ding, X.Y. (2009). Development of microsatellite markers in Dendrobium fimbriatum Hook, an endangered Chinese endemic herb. Mol. Ecol. Res., 9:373-375.

Fatima, T.; Srivastava, A.; Hanur, V.S.; Somashekar, P.V. and Srinivasa Rao, M. (2019). Genetic diversity estimates of Santalum album L. through microsatellite markers: Implications on conservation. Ame. J. Pl. Sci., 10:462-485.

Fu, R.Z.; Wang, J.; Zhang, Y.B.; Wang, Z.T.; But, P.P.; Li, N. and Shaw, P.C. (1999). Differentiation of medicinal Codonopsis species from adulterants by polymerase chain reaction-restriction fragment length polymorphism. Planta Med., 65:648-650.

Gahlaut, A.; Gothwal, A., Hooda, V. and Dabur, R. (2013). RAPD Patterns of some medicinal plants and their substitutes used in Ayurveda to identify the genetic variations. Int. J. Pharm. Pharm. Sci., 5:239-241.

Ganie, S. H.: Upadhyay, P.; Das, S and Prasad Sharma, M. (2015). Authentication of medicinal plants by DNA markers. Plant Gene, 4:83-99.

Geethika, E.; Triveni, H.N.; Srirama, R., Siva, R.; Setty, S. and Ravikanth, G. (2018). Development and characterization of microsatellite markers for Phyllanthus emblica Linn., important nontimber forest product species. J. Genet., 97(4):1001-1006.

Gokhale, M. and Bansal, Y.K. (2015). Assessment of genetic fidelity in somaclonal variants with cytological and RAPD analysis in Oroxylum indicum (L.) Vent: An endangered medicinal tree. Ind. J. Biotech., 14(4):581-584.

Goraya, G. S. and Ved, D. K. (2017). Medicinal plants in India: An assessment of their demand and supply. National Medicinal Plants Board, Ministry of AYUSH, Government of India, New Delhi and Indian Council of Forestry Research and Education, Dehradun. pp:430.

Gowda, A.P.M.; Ravi, C.S.; Narayanaswamy, M. and Raju, B. (2012). Assessment of genetic variability in Terminalia chebula using RAPD markers. Crop Res., 43(1-3):264-267.

Gupta, A.K.; Harish; Rai, M.K.; Phulwaria, M. and Shekhawat, N.S. (2011). Isolation of genomic DNA suitable for community analysis from mature trees adapted to arid environment. Gene, 487:156-159.

Gupta, P.K.; Roy, J.K. and Prasad, M. (2001). Single nucleotide polymorphisms: A new paradigm for molecular marker technology and DNA polymorphism detection with emphasis on their use in plants. Curr. Sci., 80:524-535.

Singh, G. B.; Sivalingam, R.; Mahadevan, N. P.; Chevanan, G.; Warrier, R.R.; Anandalakshmi, R. and Sivakumar V. (2005 a). High frequency polyembryony in Saraca asoca (Roxb.) de Wilde (Caesalpiniaceae): A red listed medicinal tree. Myforest, 41(4):573-582.

Singh, G. B.; Warrier, R.R.; Anandalakshmi, R.; Sivakumar, V., Sivalingam, R., Mahadevan, N. P. and Chevanan, G. (2005b). Seed germination studies in Saraca asoca (Roxb.) de Wilde. Ind. For., 31(6):841-843.

Haji, R.F.A.; Bhargava, M.; Akhoon, B.A., Kumar, A.; Brindavanam, N.B. and Verma V. (2014). Correlation and functional differentiation between different markers to study the genetic diversity analysis in medicinally important plant Plumbago zeylanica. Ind. Crops and Prod., 55:75-82.

Haque, I.; Bandopadhyay, R. and Mukhopadhyay, K. (2009a). Intraspecific variation in Commiphora wightii populations based on internal transcribed spacer (ITS-5.8S-ITS2) sequence of rDNA. Diversity, 1:89101 .

Haque, I.; Bandopadhyay, R. and Mukhopadhyay, K. (2009b). Population genetic structure of the endangered and endemic medicinal plant Commiphora wightii. Mol. Biol. Rep., 37:847-854. 
Harish, Gupta A.K.; Phulwaria, M.; Rai, M.K. and Shekhawat, N.S. (2014) Conservation genetics of endangered medicinal plant Commiphora wightii in Indian Thar Desert. Gene, 535(2):266-272.

Hebert, P.; Cywinska, A.; Ball, S. and deWaard, J.R. (2003). Biological identifications through DNA barcodes. Proc. Biol. Sci., 270:313321.

Hegde, S.; Pai, S. R. and Roy, S. (2017). Combination of DNA isolation and RP-HPLC analysis method for bark samples of Saraca asoca and its adulterant. Biotech., 7(3):208.

Hegde, S.; Pai, S. R.; Bhagwat, R. M.; Saini, A.; Rathore, P. K.; Jalalpure, S. S.; Hegde, H. V.; Sugunan, A. P.; Gupta, V. S.; Kholkute, S. D. and Roy, S. (2018). Genetic and phytochemical investigations for understanding population variability of the medicinally important tree Saraca asoca to help develop conservation strategies. Phytochem., 156: 43-54.

Hosokawa, K.; Minami, M.; Kawahara, K.; Nakamura, I. and Shibata, T. (2000). Discrimination among three species of medicinal Scutellaria plants using RAPD markers. Planta Medica, 66:270-272.

http://timesofindia.indiatimes.com/articleshow/66775547. cms?utm source $=$ contentofinterest\&utm_medium $=$ text $\& u t m \_c a m p a i g n=c p p s t$.

https://economictimes.indiatimes.com/industry/healthcare/biotech/ healthcare/77-percent-indian-households-use-ayurvedic-productspwc-report/articleshow/66773295.cms.

https://www.ibef.org/download/healthcare-jan-2019.pdf.

https://www.nmpb.nic.in/content/introduction.

Hu, Y.; Zhang, Q.; Xin, H.; Qin, L.P.; Lu, B.R.; Rahman, K. and Zheng, H. (2007). Association between chemical and genetic variation of Vitex rotundifolia populations from different locations in China: Its implication for quality control of medicinal plants. Biomed. Chromatogr., 21:967-975.

Jain, S.K. (1996). Medicinal Plants. National Book Trust. New Delhi.

Jayaram, K. and Prasad, M.N.V. (2008). Genetic diversity in Oroxylum indicum (L.) Vent. (Bignoniaceae), a vulnerable medicinal plant by random amplified polymorphic DNA marker. Afr. J. Biotechnol., 7:254-262.

Jones, C. G.; Plummer, J. A.; Barbour, E. L. and Byrne, M. (2009). Genetic diversity of an Australian Santalum album collection: Implications for tree improvement potential, Silvae Genetica, 58(1-6): 279-286.

Joshi, K.; Chavan, P.; Warude, D. and Patwardhan, B. (2004). Molecular markers in herbal drug technology. Curr. Sci., 87:159-165.

Joshi, V. K.; Joshi, A. and Dhiman, K. S. (2017). The Ayurvedic Pharmacopoeia of India: Development and perspectives. J. Ethnopharmacol., 197:32-38.

Kaushik, P. and Kumar, S. (2018). Data of de novo assembly of the leaf transcriptome in Aegle marmelos. Data Brief, 19:700-703.

Khan, S.; Mirza, K.J. and Abdin, M.Z. (2010). Development of RAPD markers for authentication of medicinal plant Cuscuta reflexa. Eur. J. Biosci., 4:1-7.

Khan, S.; Mirza, K.J.; Anwar, F. and Abdin, M.Z. (2010). Development of RAPD markers for authentication of Piper nigrum (L.). Env. We. Int. J. Sci. Tech., 5:47-56.

Kim, J. and Chung, K.W. (2007). Isolation of new microsatellite-containing sequences in Acanthopanax senticosus. J. Plant. Biol., 50:557561

Kirtikar, K.R. and Basu B.D. (2001). Indian Medicinal Plants, Oriental Enterprises, Dehradun.

Kirtikar, K.R. and Basu, B.D. (1991). Indian Medicinal Plants. Vol. 3. Bishen Singh Mahendra Pal Singh Publisher: Dehradun, India, pp:629630 .
Kohjyouma, M.; Nakajima, S.; Namera, A.; Shimizu, R.; Mizukami, H. and Kohda, H. (1997). Random amplified polymorphic DNA analysis and variation of essential oil components of Atractylodes plants. Bio. Pharm. Bull., 20:502-506.

Kojoma, M.; Iida, O.; Makino, Y.; Sekita, S. and Satake, M. (2002). DNA fingerprinting of Cannabis sativa using inter-simple sequence repeat (ISSR) amplification. Planta Med., 68:60-63.

Krishnamurthy, G.; Tiwari, S.K.; Pandey, A. and Yadav, S.S. (2015). RAPD markers for genetic diversity assessment of critically endangered medicinal plant Commiphora wightii (Arn.) Bhandari. Int. J. Curr. Res. Biosci. Pl. Biol., 2:29-34.

Krishnamurthy, T. (1993). Minor Forest Products of India. Oxford and IBH Publishing House, New Delhi, pp:92-98.

Kulhari, A.; Sheorayan, A.; Kalia, S.; Chaudhury, A. and Kalia, R.K. (2012). Problems, progress and future prospects of improvement of Commiphora wightii (Arn.) Bhandari, an endangered herbal magic, through modern biotechnological tools: A review. Trees Struct. Funct., 59:1223-1254.

Kumar, J.; Verma, V.; Shahi, A.K.; Qazi, G.N. and Balyan, H.S. (2007). Development of simple sequence repeat markers in Cymbopogon species. Planta Med., 73:262-266.

Kumar, V. (2016). Rapid molecular authentication of Ashoka [Saraca asoca (Roxb.), de Wild] vulnerable medicinal plant species and its adulterant Polyalthia longifolia Benth, by the development of SCAR markers and multiplex-PCR. Res. J. Biotech., 11(10):6068.

Li, K.; Wu, W.; Zheng, Y.; Dai, Y.; Xiang, L. and Liao, K. (2009). Genetic diversity of Fritillaria from Sichuan province based on ISSR. China Journal of Chinese Materia Medica, 34(17):2149-2154.

Li, T.; Wang, J. and Lu, Z. (2005). Accurate identification of closely related Dendrobium species with multiple species-specific gDNA probes. J. Biochem. Biophys. Methods, 62:111-123.

Little, D.P. (2014). Authentication of Ginkgo biloba herbal dietary supplements using DNA barcoding. Genome, 57:513-516.

Liu, X.; Ma, H.; Li, T.; Li, Z.; Wan, Y.; Liu, X. and Fu, L. (2018). Development of novel EST-SSR markers for Phyllanthus emblica (Phyllanthaceae) and cross-amplification in two related species. Appli. Plan. Sci., 6(7): 01169.

Madhan Shankar, S.R.; Sugumaran, G.; Kalaiyarasu, T. and Bubna, N. (2009). A rapid method for isolation of high quality DNA from leaves of Gmelina arborea (Roxb) for molecular analysis. Int. J. Biotech. Appl., 1(2):16-19.

Manoharachary, C. and Nagaraju, D. (2016). Medicinal plants for human health and welfare. Ann. Phytomed., 5:24-34.

Mawalagedera, S.M.U.P.; Janaththani, P.; Dunuwille, S.W.M.B.; Perera, G.A.D.; Weebadde, C.K.; Wijesundara, D.S.A. and Sooriyapathirana, S.D.S.S. (2015). DNA marker analysis reveals genomic diversity and putative QTL associated with drupe traits in Phyllanthus emblica L.. Cey. J. Sci. (Biological Sciences), 43(2):31-46.

Mayavel, A. and Nicodemus, A. (2017). Know Your Trees: Gmelina arborea. ENVIS Newsletter on Forest Genetic Resources and Tree Improvement (VAN VIGYAN), 4(2):2-8.

Mishra, M.; Chandra, R. and Pati, R. (2008). In vitro regeneration and genetic fidelity testing of Aegle marmelos (Corr.) plants. Ind. J. Horti., 65:6-11.

Mishra, P.; Kumar, A.; Nagireddy, A.; Shukla, A.K. and Sundaresan, V. (2017). Evaluation of single and multilocus DNA barcodes towards species delineation in complex tree genus Terminalia. PLoS ONE, 12(8): e0182836.

Mishra, K.K. (1999). New Crop Fact SHEET. Purdue University, Centre for New Crops and Plant Products, pp:1-5. https://hort.purdue.edu/ newcrop/CropFactSheets/bael.html 
Misra, A.; Shasany, A.K.; Shukla, A.K.; Darokar, M.P.; Singh, S.C.; Sundaresan, V.; Singh, J.; Bagchi, G.D.; Jain, S.P. and Khanuja, S.P.S. (2010). AFLP markers for identification of Swertia species (Gentianaceae). Gen. Mol. Res., 9:1535-1544.

Mohammad, N.; Mahesh, S.; Kumar P.; and Ansari, S.A. (2012). Genotyping of Santalum album L. accessions through cross-species transferability of SSR markers of Santalum austrocaledonicum and Santalum insulare. Sandalwood Research Newsletter, 27:1-5.

Mohan, Ch., B.; Naresh, M.; Srikanth Reddy, S.; Manoj Kumar and Prathibha Devi Cherku (2015). Genetic similarity studies of Commiphora wighti accessions by fluorescent-labeled RAPD primers. International Journal of Biotechnology and Biochemistry 13(1):55-66.

Mohan, C.; Reddy, M. S.; Naresh, B.; Kumar, S. M.; Fatima, S.; Manzelat, B. and Cherku, P. D. (2017). RAPD studies of Saraca asoca by fluorescentlabeled primers and development of micropropagation protocol for its conservation. Int. J. Appl. Agri. Res., 12(2):137-151.

Morton, J. (1987). Bael Fruit. In: Fruits of warm climates. (Ed. Morton, J.F.), Miami, Florida, USA, pp:187-190.

Morton, J. (1987). Emblic. In: Fruits of warm climates. (Ed. Morton, J.F.), Miami, Florida, USA, pp:213-217.

Mujeeb, F.; Bajpai, P.; Pathak, N. and Verma, S.R. (2017). Genetic diversity analysis of medicinally important horticultural crop Aegle marmelos by ISSR markers. Methods Mol. Biol., 1620:195-211.

Nadkarni, K.M. (1976). Indian Material Medica. Popular Prakashan Pvt. Ltd., Bombay, pp:1202-1211.

Naik, D.; Singh, D.; Vartak, V.; Paranjpe, S.; and Bhargava, S. (2009). Assessmen of morphological and genetic diversity in Gmelina arborea Roxb. New Forests, 38(1):99-115.

Narayana, D.B.A. and Johnson, T.S. (2017). Emerging scenario on industrial use of bioresources and development of models for computing access and benefit sharing (ABS) mechanisms. J. Biodivers. Biopros. Dev., 4:165.

Nayak, D.; Singh, D.R.; Sabarinathan, P.; Singh, S. and Nayak, T. (2013). Random amplified polymorphic DNA (RAPD) markers reveal genetic diversity in bael (Aegle marmelos Correa) genotypes of Andaman Islands, India. Afr. J. Biotechnol., 12(45):6055-6060.

Nayanabhirama, Udupa. (2016). Status on herbal drugs and their future perspectives. Ann. Phytomed., 5(1):1-3.

Nieri, P.; Adinolfi, B.; Morelli, I.; Breschi, M.C.; Simoni, G. and Martinotti, E. (2003). Genetic characterization of the three medicinal Echinacea species using RAPD analysis. Planta Med., 69:685-686.

Nithaniyal, S. and Parani, M. (2016). Evaluation of chloroplast and nuclear DNA barcodes for species identification in Terminalia L. Biochem. Syst. Ecol., 68:223-229.

Orwa, C.; Mutua, A.; Kindt, R.; Jamnadass, R. and Anthony, S. (2009). Agroforestree database : A tree reference and selection guide version 4.0.(http://www.worldagroforestry.org/sites/treedbs/treedata bases.asp)

Otto, L.G.; Mondal, P.; Brassac, J.; Preiss, S.; Degenhardt, J.; He, S.; Reif, J.C and Sharbel, T.F. (2017). Use of genotyping-by-sequencing to determine the genetic structure in the medicinal plant chamomile, and to identify flowering time and alpha-bisabolol associated SNPloci by genome-wide association mapping. BMC Genomics, 18(1): 599.

Padmalatha, K. and Prasad, M.N.V. (2006). Optimization of DNA isolation and PCR protocol for RAPD analysis of selected medicinal and aromatic plants of conservation concern from peninsular India. Afr. J. Biotechnol., 5(3):230-234.
Panchaksharaiah, D. S.; Chalageri, G. and Babu, U. V. (2018). In vitro Multiplication of Oroxylum indicum (L.) through apical and axillary buds and determination of genetic fidelity using RAPD markers. Asian J. Res. Bot., 1(2):1-11.

Panda, S.; Naik, D. and Kamble, A. (2015). Population structure and genetic diversity of the perennial medicinal shrub Plumbago. Ann. Bot., 48(7): $1-12$.

Pandey, M. and Changtragoon, S. (2012). Isolation and characterization of microsatellites in amedicinal plant, Phyllanthus emblica (Euphorbiaceae). Am. J. Bot., 99:468-469.

Parrota, J.A. (2001). Healing plants of peninsular India. CABI publishing, UK, pp:173-175.

Parvathy, V.A.; Swetha, V.P.; Sheeja, T.E.; Leela, N.K.; Chempakam, B. and Sasikumar, B. (2014). DNA barcoding to detect chilli adulteration in traded black pepper powder. Food Biotechnol., 28:25-40.

Parveen, I.; Gafner, S.; Techen, N.; Murch, S. J. and Khan, I. A. (2016). DNA barcoding for the identification of botanicals in herbal medicine and dietary supplements: Strengths and limitations. Planta Med., 82:1225-1235.

Parvesh, S. and Vijaya, K. (2018). Genetic variation analysis in Aegle marmelos L. plants using RAPD Molecular Markers. Res. J. Biotech., 13(8):85-89.

Patel, D. M., R.; Fougat, S.; Sakure, A. A.; Kumar, S.; Kumar, M. and. Mistry, J. G. (2016). Detection of genetic variation in sandalwood using various DNA markers, Biotech., 6(1):55.

Patel, K.; Laloo, D.; Singh, G.K.; Gadewar, M. and Patel, D.K. (2017). A review on medicinal uses, analytical techniques and pharmacological activities of Strychnos nux-vomica Linn: A concise report. Chin. J. Integr. Med., 24:1-13.

Pati, R.; Chandra, R.; Chauhan, U.K.; Mishra, M. and Srivastava, N. (2008a). In vitro clonal propagation of bael (Aegle marmelos Corr.) cv. CISH-B1 through enhanced axillary branching. Physiol. Mol. Biol. Plants, 14(4):337-346.

Pati, R.; Chandra, R.; Chauhan, U.K.; Chauhan, Upendra Mishra, Maneesh and Srivastava, Navin (2008b). In vitro plant regeneration from mature explant of Aegle marmelos Corr. cv. CISH-B2. Sci. Cult., 74:359367.

Princy, P,S.; Gangaprasad, A. and Sabu, K.K. (2015). In vitro propagation and evaluation of genetic fidelity of Aegle marmelos (L.) Correa, a highly sought-after sacred medicinal tree. Phytomorph., 65:1-10.

Rai, P.S.; Bellampalli, R.; Dobriyal, R.M.; Agarwal, A.; Satyamoorthy, K. and Narayana, D.B.A. (2012). DNA barcoding of authentic and substitute samples of herb of the family Asparagaceae and Asclepiadaceae based on the ITS2 region. J. Ayurveda Integr. Med., 3:136-140.

Rajasekharan, P.E.; Kareem, V.K.; Ravish, B.S. and Mini, S. (2017). Genetic diversity in Oroxylum indicum (L.) Vent, a threatened medicinal plants from India by ISSR analysis. Ind. J. Biotechnol., 16(3):357365 .

Rajeswara Rao, B.R. (2016). Genetic diversity, genetic erosion, conservation of genetic resources, and cultivation of medicinal plants. In: Genetic diversity and erosion in plants. Sustainable development and biodiversity (Ed. Ahuja M., Jain S.) Vol 8, Springer, Cham, Switzerland.

Esha, R. and Patel, I. (2017). Genetic fidelity of micropropagated Oroxylum indicum (L.) Vent. by RAPD marker. Plant Archives, 17(2):15541558 .

Rao, M.N. (2004). Mapping genetic diversity of Sandal (Santalum album L.) genetic resources in peninsular India using biochemical and molecular markers: Lessons for in situ conservation. Ph.D. Thesis, Forest Research Institute, Dehradoon, India. 
Rao, M.N.; Ganeshaiah, K.N. and Uma Shaanker, R. (2007). Assessing threats and mapping sandal (Santalum album L.) resources in peninsular India: Identification of genetic hot-spot for in situ conservation. Conserv. Genet., 8:925-935.

Resmi, M.S.; Verma, P.; Gokhale, R.S. and Soniya, E.V. (2013). Identification and characterization of a Type III polyketide synthase involved in quinolone alkaloid biosynthesis from Aegle marmelos Correa. J. Biol. Chem., 288:7271-7281.

Resmi, M.S.; Vivek, P.J. and Soniya, E.V. (2015). Over-expression of bael quinolone synthase in tobacco improves plant vigor under favorable conditions, drought, or salt stress. FEBS Lett., 589:332-341.

Rosario Sachin, A. (2013). Mapping genetic diversity of $S$. ascoa Roxb. De Wilde. M.Sc Thesis, UAS, Bengaluru, pp:160.

Saha, J.; Gupta, K. and Gupta, B. (2015). Phylogenetic analyses and evolutionary relationships of Saraca asoca with their allied taxa (Tribe-Detarieae) based on the chloroplast matK gene. J. Plant Biochem. Biotechnol., 24(1):65-74.

Saini, A.; Hegde, S.; Hegde, H. V.; Kholkute, S. D. and Roy, S. (2018). Assessment of genetic diversity of Saraca asoca (Roxb.) De Wilde: a commercially important, but endangered, forest tree species in Western Ghats, India. New Zea. J. For. Sci., 48(1):17-28.

Sairkar, P.K.; Chouhan, S.; Batav, N. and Sharma, R. (2013). Optimization of DNA isolation process and enhancement of RAPD PCR for low quality genomic DNA of Terminalia arjuna. J. Genet. Eng. Biotechnol., 11:2-9.

Sairkar P.K.; Chouhan, S.; Sen, A.; Sharma, R. and Singh, R.K. (2017). Genetic drift in six cultivated populations of Terminalia arjuna. J. Appl. Bio. Biotech., 5(4):48-56.

Sairkar, P.K.; Sharma, A. and Shukla, N.P. (2016). SCAR marker for identification and discrimination of Commiphora wightii and $C$. myrrha. Mol. Bio Int., pp:1-11. https://doi.org/10.1155/2016/ 1482796 .

Samantaray. S.; Geetha, K.A.; Hidayath, K.P. and Maiti, S. (2010). Identification of RAPD marker linked to sex determination in guggal (Commiphora wightii (Arnott.) Bhandari. Plant Biotech. Rep., 4(1):95-99.

Samantaray. S.; Hidayath, K.P. and Maiti, S. (2009). An isolation protocol of genomic DNA from Commiphora wightii (Arnott) Bhandari: An endangered medicinal plant. Int. J. Integr. Biol., 6(3):127-131.

Sangeetha, N.; Mercy, S.; Kavitha, M.; Selvaraj, D.; Sathishkumar, R. and Ganesh, D. (2010). Morphological variation in the Indian gooseberries (Phyllanthus emblica and Phyllanthus indofischeri) and the chloroplast trnL (UAA) intron as candidate gene for their identification. Pl. Gen. Resour., 8(3):191-197.

Sankanur, M. (2013). Reproductive biology, molecular profiling and biochemical analysis of Terminalia chebula (Retz.). Ph.D. Thesis. Dr. Y. S. Parmar University of Horticulture and Forestry, Solan (H.P)

Sarwat, M.; Das, S. and Srivastava, P.S. (2011a). Estimation of genetic diversity and evaluation of relatedness through molecular markers among medicinally important trees: Terminalia arjuna, T. chebula and T. bellerica. Mol. Bio. Rep., 38:5025-5036.

Sarwat, M.; Das, S. and Srivastava, P.S. (2011b). A comparison of the AFLP and SAMPL molecular markers in characterizing genetic diversity of Terminalia arjuna : The backbone of tasar silk industry. Plant Syst. Evol., 293:13-23.

Sarwat, M.; Negi, M. and Lakshmikumara, M.; Tyagi, A.K.; Das, S. and Srivastava, P.S. (2006). A standardized protocol for genomic DNA isolation from Terminalia arjuna for genetic diversity analysis. Elect. J. Biotechnol., 9:86-91.
Schmelzer, G,H. and Gurib-Fakim, A. (2013). Plant resources of tropical Africa (PROTA), medicinal plants-2, Backhuys Publishers, Wageningen, Netherlands., pp:384.

Seethapathy, G.S.; Raclariu-Manolica, A.C.; Anmarkrud, J.A.; Wangensteen, H. and de Boer, H.J. (2019). DNA metabarcoding authentication of ayurvedic herbal products on the European market raises concerns of quality and fidelity. Front. Plant Sci. 10:68. doi: 10.3389/ fpls.2019.00068

Seethapathy, G. S.; Ganesh, D.; Santhosh Kumar, J. U.; Senthilkumar, U.; Newmaster, S. G.; Ragupathy, S.; Uma Shaanker, R. and Ravikanth, G. (2015). Assessing product adulteration in natural health products for laxative yielding plants, Cassia, Senna, and Chamaecrista, in Southern India using DNA barcoding. Int. J. Legal Med., 129:693700 .

Seethapathy, G.S.; Balasubramani, S.P. and Venkatasubramanian, P. (2014). NrDNA ITS sequence based SCAR marker to authenticate Aconitum heterophyllum and Cyperus rotundus in ayurvedic raw drug source and prepared herbal products. Food Chem., 145:1015-1020.

Sen Sarma, P.K. (1982). Sandalwood: Its cultivation and utilization. In: Cultivation and Utilization of Aromatic Plants. (Eds: Atal, C.K. and B.M. Kapur), Regional Research Laboratory, CSIR, Jammu Tawi, pp:395-495.

Shaanker, R.U.; Ganeshaiah, K.N.; Rao, M.N. and Aravind, N.A. (2004). Ecological consequences of forest use from genes to ecosystem: A case study in the Biligiri Rangaswamy temple wildlife sanctuary, South India. Cons. Soc. 2:347-363.

Shanmughanandhan, D.; Ragupathy, S.; Newmaster, S. G.; Mohanasundaram, S. and Sathishkumar, R. (2016). Estimating herbal product authentication and adulteration in India using a vouchered, DNA-based biological reference material library. Drug Saf., 39:1211-1227.

Sharma, C.K. and Sharma, V. (2015). Analysis of Aegle marmelos (L.) Corr. diversity using citrus based microsatellite markers. J. Appl. Horti., 17:217-221.

Sharma, P.; Sharma, S.; Yadav, S.; Srivastava, A.; Varma, A.; Luhana, K. and Shrivastava, N. (2018). Categorization of Saraca asoca and Polyalthia longifolia, using chemical and genetic fingerprinting associated with multivariate statistical analysis. J. Appl. Res. Med. Arom. Plan., 9:91-96.

Sharma, S. and Shrivastava, N. (2016). DNA-based simultaneous identification of three Terminalia species Targeting Adulteration. Pharmacogn. Mag., 12(3):379-383.

Shashidhara, G.; Hema, M.V.; Koshy, B. and Farooqi, A.A. (2003). Assessment of genetic diversity and identification of core collection in sandalwood germplasm using RAPDs. J. Hort. Sci. Biotech., 78:528536.

Shaw, P.C.; Ngan, F.N.; But, P.P.H. and Wang, J. (2002). Molecular markers in Chinese medicinal materials. In: Authentication of Chinese medicinal materials by DNA technology (Ed. Shaw, P.C., Wang. J., But, P.P.H.), World Scientific Publishing Co., Hong Kong, pp:123.

Shen, J.; Ding, X.Y.; Ding, G.; Liu, D.Y.; Tang, F. and He, J. (2006). Studies on population difference of Dendrobium officinale establishment and optimization of the method of ISSR fingerprinting marker. Zhongguo Zhong Yao Za Zhi, 3:291-294.

Shi, H.M.; Wang, J. and Tu, P.F. (2009). Identification of Cistanche species by chemical and inter-simple sequence repeat fingerprinting. Biol. Pharm. Bull., 32(1):142-146.

Shim, Y.H.; Choi, J.H.; Park, C.D. and Lim, H.J. (2003). Molecular differentiation of Panax species by RAPD analysis. Arch. Pharm. Res., 26:601-605. 
Shrivastava, A.; Panda, M.K. and Acharya, L. (2015). Molecular maker based assessment of genetic diversity of Saraca asoca (Roxb.)Wilde: An endangered medicinal plant. New Horizons in Biotechnology (NHBT), November, 22-25, Tiruvanthapuram, India.

Singh, S. (2003). Genetic diversity in aonla (Emblica officinalis Gaertn.). Indian Hort., 42:7-10.

Singh, S.; Krishna, T.H.A.; Kamalraj, S.; Kuriakose, G.C.; Valayil, J.M. and Jayabaskaran, C. (2015). Phytomedicinal importance of Saraca asoca (Ashoka): An exciting past, an emerging present and a promising future. Curr. Sci., 109(10):1790-1801.

Sivakumar, V.; Anandalakshmi, R.; Warrier, R.R.; Tigabu, M.; Odén, P.C.; Vijayachandran, S.N.; Geetha, S. and Singh, B.G. (2006). Effects of presowing treatments, desiccation and storage conditions on germination of Strychnos nux-vomica seeds, a valuable medicinal plant. New Forests, 32(2):121-131.

Sivalingam, D.; Rajendran, R. and Anbarasan, K. (2016). DNA barcoding of highly threatened sacred plant, Aegle marmelos L. Int. J. Curr. Res. Biosci. Plant Biol., 3(5):88-96.

Song, Z.; Li, X.; Wang, H. and Wang, J. (2010). Genetic diversity and population structure of Salvia miltiorrhiza in China revealed by ISSR and SRAP. Genetica, 138:241-249.

Sonu Bharti. (2018). An improved protocol for genomic DNA extraction and purification from leaves of Terminalia arjuna (Roxb.) Wight and Arnis. International Res. J. Bio. Sci., 7(10):10-16.

Srinivasan, V.V.; Sivaramakrishnan, V.R.; Rangaswamy, C.R.; Ananthapadmanabha, H.S. and Shanakaranarayana, K.H. (1992). Sandal. ICFRE, Dehradoon. pp:233.

Srirama, R.; Senthilkumar, U.; Sreejayan, N.; Ravikanth, G.; Gurumurthy, B.R.; Shivanna, M. B.; Sanjappa, M., Ganeshaiah, K.N. and Shaanker, R.U. (2010). Assessing species admixtures in raw drug trade of Phyllanthus, a hepato-protective plant using molecular tools. J. Ethnopharmacol., 130(2):208-215.

Srivastava, J.; Lambert, J. and Vietmeyer, N. (1996). Medicinal plants: An expanding role in development. World Bank Technical Paper No. 320, World Bank Publications, Washington, DC.

Srivastava, S. and Rawat, A. K. (2013). Quality evaluation of Ayurvedic crude drug daruharidra, its allied species, and commercial samples from herbal drug markets of India. Evidence-Based Complementary and Alternative Medicine, 10.1155/2013/472973.

Sucher, N.J. and Carles, M.C. (2008). Genome-Based approaches to the authentication of medicinal Plants. Plant Med., 74:603-623.

Suma, T.B. and Balasundaran, M. (2004). Genetic diversity of eight Santalum album provenances of India based on RAPD analysis. Ind. J. Genet. Plant Breed., 64:167-168.

Sumangala, R. C.; Shaanker, R. U.; Dayanandan, S.; Vasudeva, R. and Ravikanth, G. (2013). Identification of novel microsatellite markers for Saraca asoca, a medicinally important tree species in India. J. Genet., 92:93-95.

Senapati, S.K., Das, G.K.; Aparajita,S. and Rout, G.R. (2012). Assessment of genetic variability in the Asoka tree of India. Biodiversity, 13(1): $16-23$.

Suthar, S. and Ramawat, K.G. (2010). Growth retardants stimulate guggulsterone production in the presence of fungal elicitor in fedbatch cultures of Commiphora wightii. Plant Biotechnol. Rep., 4:9-13.

Swetha, V. P.; Parvathy, V. A.; Sheeja, T. E. and Sasikumar, B. (2017). Authentication of Myristica fragrans Houtt. using DNA barcoding. Food Control, 73:1010-1015.

Swetha Swetha, V.P.; Parvathy, V.A.; Sheeja, T. E. and Sasikumar, B. (2014). DNA barcoding for discriminating the economically important Cinnamomum verum from its adulterants. Food Biotechnol., 28:183-194.
Theerakulpisut, P.; Kanawapee, N.; Maensiri, D.; Bunnag, S. and Chantaranothai, P. (2008). Development of species-specific SCAR markers for identification of three medicinal species of Phyllanthus. J. System. Evol., 46(4):614-621

Thomson, L.; Doran, J. and Clarke, B. (2018). Trees for life in Oceania: Conservation and utilisation of genetic diversity. Australian Centre for International Agricultural Research, Canberra.

Tsoi, P.Y.; Woo, H.S.; Wong, M.S.; Chen, S.L.; Fong, W.F.; Xiao, P.G. and Yang, M.S. (2003). Genotyping and species identification of Fritillaria by DNA chips. Yaoxue Xuebao, 38:185-190.

Urumarudappa, S.K.J.; Gogna, N.; Newmaster, S.G.; Venkatarangaiah, K.; Subramanyam, R.; Saroja, S.G.; Gudasalamani, R.; Dorai, K. and Ramanan, U.S. (2016). DNA barcoding and NMR spectroscopy based assessment of species adulteration in the raw herbal trade of Saraca asoca (Roxb.) Willd, an important medicinal plant. Int. J. Legal Med., 130: $1457-1470$.

Valiathan, M. S. (2006). Ayurveda: Putting the house in order. Curr. Sci., 90:5-6.

Wang, H.; Li, G.; Kwon, W. S. and Yang, D. C. (2016). Development of EST intron-targeting SNP markers for Panax ginseng and their application to cultivar authentication. Int. J. Mol. Sci., 17(6):884.

Wang, J.; Ha, W.Y.; Ngan, F.N.; But, H.P.P. and Shaw, P.C. (2001). Application of sequence characterized amplified region (SCAR) analysis to authenticate Panax species and their adulterants. Planta Med., 67:781-783.

Wang, L.C.; Cao, Y.H.; Xing, X.P. and Ye, J.N. (2005). Fingerprint studies of Radix scutellariae by capillary rlectrophoresis and high performance liquid chromatography. Chromatographia, 62:283288.

Wang, P.; Huang, F.; Thou, L.; Cao, L.; Liang, S.; Xu, H. and Liu, J. (2000). Analysis of Ammomum villosum species and some adulterants of Zingiberaceae by RAPD. Z. Yao. Cai., 23:71-74.

Warrier, P.K.; Nambiar, V.P.K. and Ramankutty, C. (2002). Indian medicinal plants : A compendium of 500 species. Orient Longman, Chennai, 5:192.

Warrier, P.K.; Nambiar, V.P.K. and Ramankutty, C. (1995). Oroxylum indicum. In: A compendium of 500 Species, Indian Medicinal Plants, Vol.IV. Madras, Orient Longman Ltd., pp:186-190.

Warrier, P.K. (1994). Indian Medicinal Plants. A compendium of 500 species, $4: 381$

Warrier, P.K., Nambiar, Å.K. and Ramankutty, C. (1987). Indian Medicinal Plants. A compendium of 500 species. Vol. 3. Madras: Orient Longman Publications, pp:256-263.

Warrier, P.K. (2002). A dictionary of Indian raw materials and industrial products. New Delhi: Publications and Information Directorate, Council of Scientific and Industrial Research; pp:387.

Warrier, R. R.; Anandalakshmi, R.; Sivakumar, V.; Sivalingam, R. and Singh B.G. (2007). Seed biology of Saraca asoca. In: National Seminar on Conservation, Cultivation and Sustainable Utilization of Saraca Asoca, Kerala Forest Research Institute, Peechi, pp:16-17.

Warrier, R.R.; Jasmine, Viji, and Priyadharshini, P. (2010). In vitro propagation of Aegle marmelos L. (Corr.) from mature trees through enhanced axilliary branching. Asian J. Experi. Bio. Sci., 1(3):669-676.

Warrier, R.R.; Singh, G.B.; Kumar, S.; Sivakumar, V. and Anandalakshmi, R. (2003). Standardization of seed handling techniques for commercially important medicinal plants. Project Completion Report. ICFRE, pp:40.

Warrier, R.R.; Anandalakshmi,R.; Sivakumar, V. and Singh, G.B.B. (2016). Establishing propagation methods for Oroxylum indicum. ENVIS Newsletter on Medicinal Plants, 9(1-4):14-15. 
Warude, D.; Chavan, P.; Joshi, K. and Patwardhan, B. (2006). Development and application of RAPD-SCAR marker for identification of Phyllanthus emblica Linn., Biol. Pharm. Bull., 29:2313-2316.

Warude, D.; Chavan, P.; Joshi, K. and Patwardhan, B. (2003). DNA isolation from fresh and dry plant samples with highly acidic tissue extracts. Plant Mol. Bio. Rep., 21(4):467a-467f.

Vassou, S. L.; Kusuma, G. and Parani, M. (2015). DNA barcoding for species identification from dried and powdered plant parts: A case study with authentication of the raw drug market samples of Sida cordifolia. Gene, 559:86-93.

Vassou, S. L., Nithaniyal, S., Raju, B., and Parani, M. (2016). Creation of reference DNA barcode library and authentication of medicinal plant raw drugs used in Ayurvedic medicine. BMC Complement. Altern. Med., 16:186. doi: 10.1186/ 12906-016-1086-0

Ved, D. K. and Goraya, G. S., (2008). Demand and supply of medicinal plants in India, NMPB, New Delhi and FRLHT, Bangalore, India. pp: 225 .

Wee, A.K.S.; Li, C.H.; Dvorak, W.S. and Hong, Y. (2011). Genetic diversity in natural populations of Gmelina arborea : Implications for breeding and conservation, N. For. 43:411-428.

Veldman, S.; Gravendeel, B.; Otieno, J. N.; Lammers, Y.; Duijm, E.; Nieman, A.; Bytebier, B.; Ngugi, G.; Martos, F., van Andel, T.R. and de Boer, H.J. (2017) High-throughput sequencing of African chikanda cake highlights conservation challenges in orchids. Biodivers. Conserv., 26:2029 2046

World Health Organization. (1998). Quality control methods for medicinal plant materials. World Health Organization.http://www.who.int/ iris/handle/10665/41986. pp:115.
Wolf, H.T.; Berg, T.; Czygan, F.C.; Mosandl, A.; Winckler, T.; Zundorf, I. and Dingerman, T. (1999). Identification of Melissa officinalis subspecies by DNA fingerprinting. Planta Med., 66:270-272.

Vyas, P. and Joshi, R. (2015). Use of ISSR marker for the study of genetic polymorphism amond population of Commiphora wightii (Arnott) Bhandari. Int. J. Curr. Adv. Res., 6:117-121.

Yamasaki, M.; Sato, A.; Shimomura, K.; Saito, K. and Murakoshi, I. (1994). Genetic relationships among Glycyrrhiza plants determined by RAPD and RFLP analysis. Bio. Pharm. Bull., 17:1529-1531.

Yang, D.Y.; Fushimi, H.; Cai, S.Q. and Komatsu, K. (2004). Polymerase chain reaction restriction fragment length polymorphism (PCR-RFLP) and amplification refractory mutation system (ARMS) analysis of medicinally used Rheum species and their application for identification of Rheum rhizoma. Biol. Pharm. Bull., 27:661669.

Zhang, K.Y.B.; Leung, H.W.; Yeung, H.W. and Wong, R.N.S. (2001). Differentiation of Lycium barbarum from its related Lycium species using random amplified polymorphic DNA. Planta Med., 67:379-381.

Zhang, Y.B.; Shaw, P.C.; Sze, C.W.; Wang, Z.T. and Tong, Y. (2007). Molecular authentication of Chinese herbal materials. J. Food Drug Anal., 15:1-9.

Zhou, J.; Wang,W.; Liu, M. and Liu, Z. (2014). Molecular authentication of the traditional medicinal plants, Peucedanum praeruptorum and its substitutes and adulterants by DNA-barcoding technique. Pharmacogn. Mag., 10:385-390.

Citation: Rekha R. Warrier, Geeta Joshi and A.N. Arunkumar (2019). DNA fingerprinting in industrially important medicinal trees. Ann. Phytomed., 8(1):19-35. 